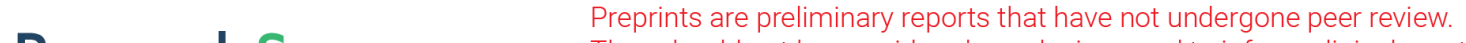 They should not be considered conclusive, used to inform clinical practice, or referenced by the media as validated information. \\ Profiling of seasonal variation in and cancer risk assessment of benzo (a) pyrene and heavy metals in drinking water from Kirkuk city, Iraq
}

\section{Awaz Bahrooz Mohammed}

University of Kirkuk

Siraj Muhammed Goran ( $\square$ siraj.abdulla@su.edu.krd)

Salahaddin University - Erbil College of Science https://orcid.org/0000-0002-1957-3621

Abhrajyoti Tarafdar

Korea University Division of Environmental Science and Ecological Engineering

\section{Research Article}

Keywords: Benzo(a)pyrene, heavy metals, drinking water, cancer risk, Monte Carlo simulation

Posted Date: April 30th, 2021

DOI: https://doi.org/10.21203/rs.3.rs-385414/v1

License: (c) (i) This work is licensed under a Creative Commons Attribution 4.0 International License.

Read Full License

Version of Record: A version of this preprint was published at Environmental Science and Pollution Research on November 15th, 2021. See the published version at https://doi.org/10.1007/s11356-02117314-8. 


\title{
Profiling of seasonal variation in and cancer risk assessment of benzo(a)pyrene and heavy metals in drinking water from Kirkuk city, Iraq
}

\author{
Awaz Bahrooz Mohammed ${ }^{1}$, Siraj Muhammed Abdulla Goran ${ }^{2}$ and Abhrajyoti Tarafdar ${ }^{3}$ \\ ${ }^{1}$ Biology Department, College of Science, Kirkuk University, Iraq; \\ ${ }^{2}$ Environmental Science and Health Department, College of Science, Salahaddin University-Erbil, Kurdistan \\ Region-Iraq; https://orcid.org/0000-0002-1957-3621 \\ ${ }^{3}$ Division of Environmental Science and Ecological Engineering, Korea University, Republic of Korea. \\ Corresponding Author: Siraj Muhammed Abdulla Goran; siraj.abdulla@su.edu.krd \\ Contact Numbers: +9647504546250; +9647724466884; +9647808227000 \\ Abstract
}

The Lesser Zap River is the main tributary of the Tigris and is used as a main source of drinking water in Kirkuk city through the General Kirkuk project. Water samples at 13 sites were analyzed for heavy metals (cobalt, lead, manganese, copper) and benzo(a)pyrene using 2 methods of analysis (high-performance liquid chromatography (HPLC) and enzyme-linked immunosorbent assay (ELISA) kits). Risk evaluation for benzo(a)pyrene and lead in water samples was accomplished by Monte Carlo simulation.

The highest concentrations of B(a)P were recorded at sites S7 and S5, with levels of 0.192 and $0.122 \mu \mathrm{g}$ $\mathrm{L}^{-1}$ detected by HPLC and ELISA, respectively. The WHO guidelines for benzo[a]pyrene in drinking water recommend $0.0007 \mathrm{mg} \mathrm{L}\left(0.7 \mu \mathrm{g} . \mathrm{L}^{-1}\right)$, and none of the samples surpassed this level; moreover, $\mathrm{B}(\mathrm{a}) \mathrm{P}$ levels exceeded EPA standards in 2014 (0.01 ppb), particularly when the liquid-liquid extraction method with HPLC was used.

Carcinogenic risks for human adults and children exist and are highest during the rainy season as compared with the carcinogenic risk during the dry season; risks for children exceed those of adults. This indicates that the 2 nd round of sampling (winter season) harbors more carcinogenic risk than the 1st round of sampling (dry season).

Key Words: Benzo(a)pyrene, heavy metals, drinking water, cancer risk, Monte Carlo simulation.

\section{Introduction:}

Aquatic pollutants mainly consist of trace elements, fertilizers, microscopic organisms, and toxic organic substances (WHO 2011; Nambatingar et al. 2017).

Heavy elements are important environmental toxic pollutants, and their toxicity is becoming more of a concern for ecological, evolutionary, nutritional, and environmental reasons (Nagajyoti et al. 2010). 
Water pollution has direct effects on human health, while sewage and industrial effluents exert indirect effects on human health through intake of foods irrigated with contaminated water. According to the World Health Organization 2011, more than $80 \%$ of human diseases have origins in water. Heavy elements in surface and ground water containing $\mathrm{Mn}, \mathrm{Cr}, \mathrm{Fe}, \mathrm{Cu}, \mathrm{Ni}, \mathrm{Cd}$, and $\mathrm{Zn}$ have negative effects on human physiology (Singh et al. 2011).

Heavy elements can be present in trace amounts in water and are still harmful to humans and other ecosystems, depending on factors such as the organisms exposed to an element, its composition, its biological function, and the length of time the organisms are exposed to the element. The relationships between organisms are described by food chains and food webs. Therefore, contamination of water by heavy elements affects all organisms, particularly those feeding at the highest level (Lee et al. 2002). The presence of heavy elements in drinking water may be related to transferred pipeline incidents.

These elements bind to protein sites by displacing original metals from their natural binding sites, causing cell malfunction and, ultimately, toxicity. The binding of heavy elements to DNA and nuclear proteins is thought to be the primary cause of oxidative degradation of biological macromolecules, according to previous studies (Flora et al. 2008). Ionic oxidation stress is caused by lead toxicity in living cells. Many studies have shown that oxidative stress in living cells is caused by an imbalance between the production of antioxidants to detoxify or restore reactive intermediates and the production of free radicals. The ability of lead metal ions to substitute for other divalent cations such as $\mathrm{Fe}^{2+}, \mathrm{Ca}^{2+}$, and $\mathrm{Mg}^{2+}$, and the monovalent cation $\mathrm{Na}^{+}$, ultimately disturbs the biological metabolism of the cell. Lead can substitute for calcium even at picomolar concentrations, affecting protein kinase C, which regulates neural excitation and memory storage (Jaishankar et al. 2014).

PAHs in the environment consist of parent compounds and alkylated homologs. Such compounds (PAHs) are of great environmental concern due to their persistence, bioaccumulation and toxic effects (Badawy and Emababy 2010). The health effects of single polycyclic aromatic hydrocarbons (PAHs) may be apparent under circumstances of high exposure. Long-term exposure may be more important in terms of overall public health (Carpenter et al. 2002).

Among the sixteen PAH compounds, benzo(a)pyrene has sparked widespread interest due to its carcinogenic potential and pentacyclic high-molecular-weight PAH structure. Benzo(a)pyrene and other polycyclic aromatic hydrocarbons (PAHs) are widespread environmental contaminants formed by incomplete combustion of organic material (IARC 2010). B(a)P has been classified by the US EPA as a probable human carcinogen. There is an increase in the risk of developing cancer even at low levels, and long-term exposure through drinking water is considered to represent a probable human carcinogenic risk according to the WHO (2011). B(a)P should not be present at concentrations above $0.2 \mu \mathrm{g} \mathrm{L} \mathrm{L}^{-1}$, the maximum contaminant level (MCL). Water storage tanks and distribution lines may be the major sources of $\mathrm{B}(\mathrm{a}) \mathrm{P}$ in drinking water. $\mathrm{B}(\mathrm{a}) \mathrm{P}$ in tap water primarily results from the presence of PAH-containing materials in water storage and distribution systems (ATSDR 1990), and the presence of PAH-containing coal tar coatings on drinking water distribution pipes and storage tanks may be the primary source of B(a)P in drinking water (OEHHA 2010).

Health effects from overexposure to heavy metals and other chemical components in water are dependent on the amount of drinking water, chemical form, age at exposure, nutritional status and lifestyle 
(U.S. Environmental Protection Agency 2010). Copper is an essential element in human life, but chronic exposure

to copper from drinking water can result in health problems such as anemia and liver and kidney damage. Even in small doses, lead can affect the central nervous system, brain, and kidneys, resulting in death or permanent damage. Manganese is an essential element for organisms and occurs naturally in many food sources. Adverse effects can result from both deficiency and overexposure (WHO 2003).

The main objective of this study is to provide insight into the profiles of heavy metals and benzo(a)pyrene in drinking water of Kirkuk city and produce a probabilistic cancer risk simulation with respect to human health.

\section{Description of the study area}

The Lesser Zab River originates in the Islamic Republic of Iran and is home to the Dokan Dam (6.8 $\left.\mathrm{km}^{3}\right)$. The river basin of $21,475 \mathrm{~km}^{2}$ (of which 74 percent is in Iraqi territory) generates approximately $7.17 \mathrm{~km}^{3}$, with an annual safe yield of $5.07 \mathrm{~km} 3$ after construction of the Dokan Dam (OXFAM 2017). The Kirkuk drinking water treatment plant is located on the border of the Lesser Zab River at coordinates $35.67943^{\circ}, 44.08357^{\circ}$.
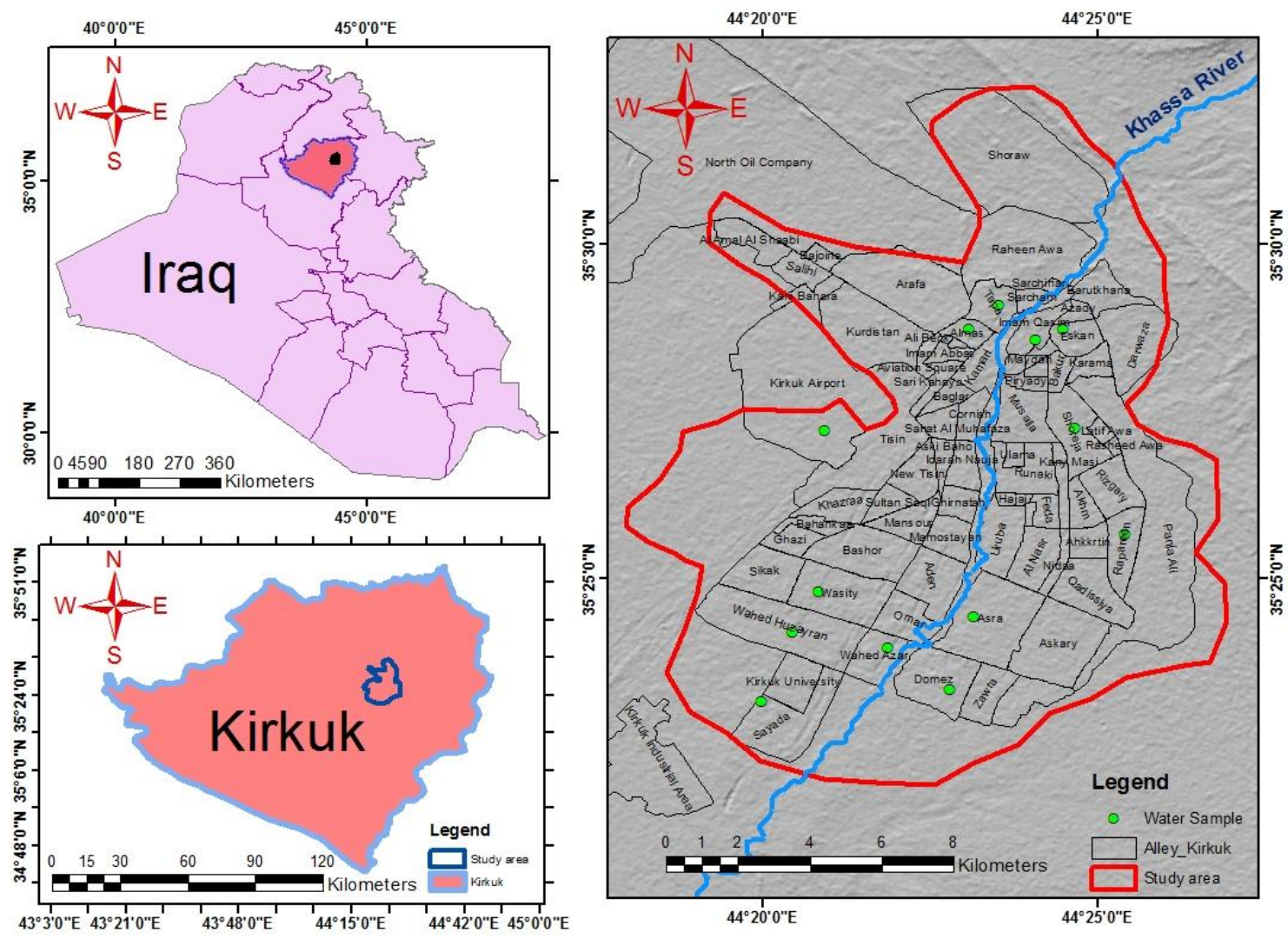

(a) 


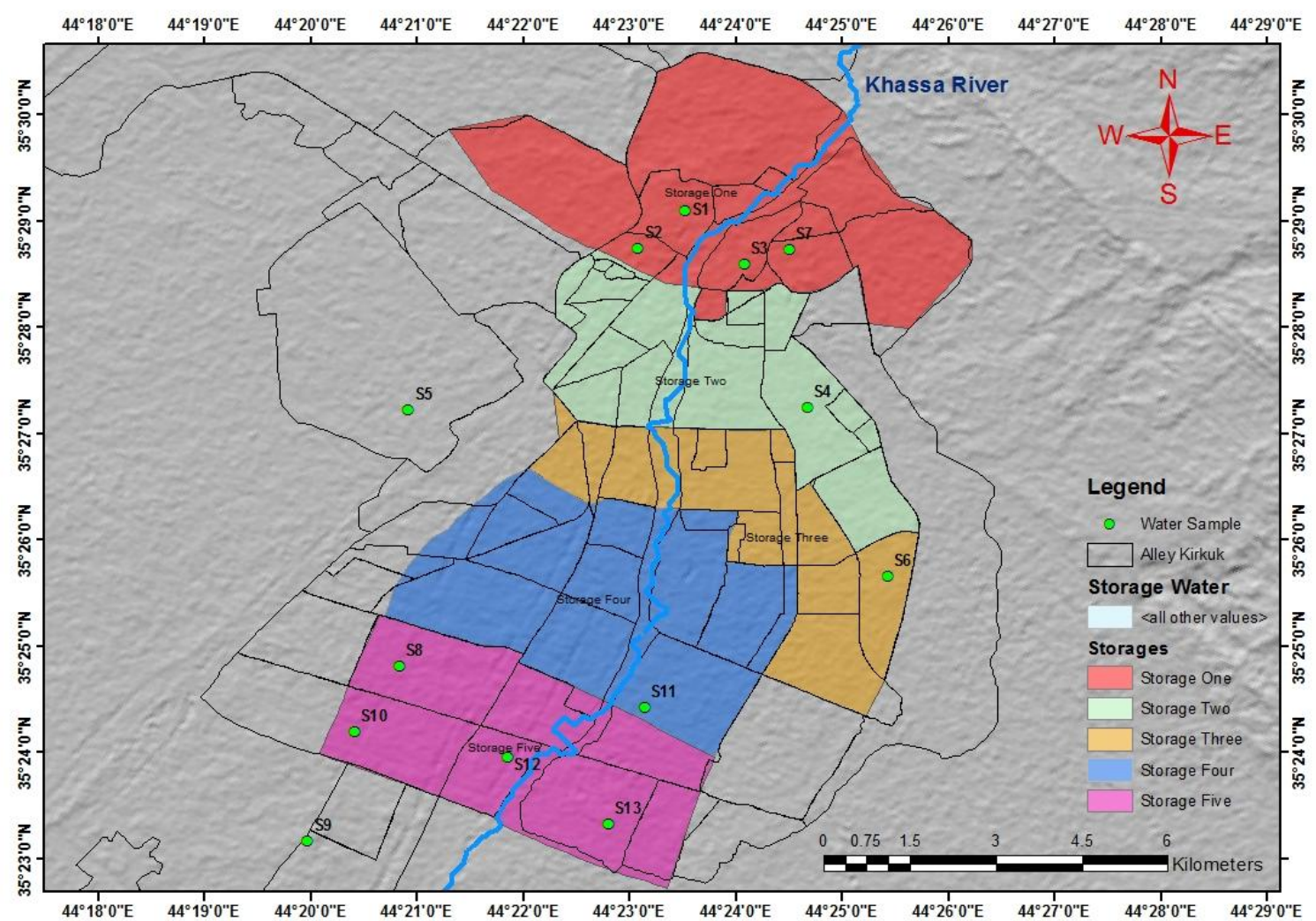

(b)

Fig. 1 (a) Iraq map and sampling sites in Kirkuk city and (b) water tanks ST1, ST2, ST3, ST4 and ST5 that feed all areas within Kirkuk city.

Kirkuk, the location for which this study was carried out, with an estimated population density of 950,000 , is one of the vital cities within northern Iraq (longitude $44^{\circ} 24^{-}$and latitude $35^{\circ} 28^{-}$). Kirkuk city drains its water for drinking from the Lesser Zab River (one of the longest tributaries of the Tigris) and groundwater in some areas that have not been linked with the Kirkuk unified treatment plant. The water treatment plant in Kirkuk city includes six units: receiving well, flash mixture, clariflocculator, filters, ground tanks and high lift pumping station. After treatment, water is stored in the main storage tank (ST1) and four other storage tanks (ST2, ST3, ST4 and ST5) that feed all areas within Kirkuk city (Kirkuk Water Directorate) (OXFAM 2017). Thirteen sites within Kirkuk city were selected for collection of water samples (Fig. 1) (using clean acid-washed polyethylene bottles during June 2017 and December 2018) to prevent any problems regarding distribution networks or pipelines that transfer water to the houses (Baird et al. 2017) (Table S1).

\section{Material and methods}

\section{Extraction and analysis of benzo(a)pyrene in water samples}

110 The liquid-liquid extraction method described by UNEP, 1989, was used to extract B(a)P from two liters of water

111 sample with $60 \mathrm{~mL}$ of $\mathrm{CCl}_{4}$. This step was performed twice, and the combined extracts were transferred into a

112 flask for further preparation. Organic extracts were then evaporated to dryness by a rotary evaporator $\left(50^{\circ} \mathrm{C}\right.$ for 
bath and $10^{\circ} \mathrm{C}$ temperature for water refrigerator circulator). After evaporation, the residue was dissolved in 5 $\mathrm{mL}$ acetonitrile and then concentrated to $1 \mathrm{~mL}$ under gentle $\mathrm{N}_{2}$ treatment. The extract was then stored at $-20^{\circ} \mathrm{C}$ until analysis by high-performance liquid chromatography (YL9100 HPLC system) at the Ministry of Sciences and Technology, Baghdad, Iraq. Approximately $12 \mu \mathrm{L}$ of extract was injected into a capillary column of stationary phase with dimensions of $15 \mathrm{~cm} \times 4.6 \mathrm{~mm}$ and then determined using a UV detector at $254 \mathrm{~nm}$ wavelength. Water was the mobile phase, and the flow rate of acetonitrile was $1.5 \mathrm{~mL} / \mathrm{min}$. Peaks on the chromatogram were identified and compared with control retention time and spectra.

\section{Enzyme-linked Immunosorbent Assay (ELISA) test kit Method}

$B(a) P$ exists at very low levels in drinking water: to achieve high recovery, high sensitivity and high reproducibility, a B(a)P ELISA test kit (MaxSignal ${ }^{\circledR}$ Benzo(a)pyrene (B(a)P) ELISA Test Kit) was used as another method for measuring levels and then compared with HPLC. It is a competitive enzyme immunoassay method. A $1.5 \mathrm{~mL}$ water sample was taken at a $\mathrm{pH}$ range between $6.5-7.5$ and adjusted by $0.1 \mathrm{M} \mathrm{HCl}$ or $\mathrm{NaOH}$. A B(a)P conjugate coating was applied in the plate wells. If the target is present in the sample, it will compete for antibody binding by preventing the antibody from binding to the B(a)P attached to the wells. After adding substrate, the color of the secondary antibody tagged with a peroxide enzyme strengthened, and the target primary antibody associated with the $\mathrm{B}(\mathrm{a}) \mathrm{P}$ coating the plate wells, resulting in an inverse relationship with the target concentration in the sample. According to the Max Signal Benzo(a)pyrene ELISA test manufactured by Bio Scientific, the detection limit (sensitivity) is $0.3 \mu / L(p p b)$.

\section{Extraction and analysis of heavy metals}

134 For heavy metals, polyethylene containers were used for sample collection. Sampling tools and containers were contamination free. Containers were washed with $10 \% \mathrm{v} / \mathrm{v}$ nitric acid, rinsed several times with deionized water and then collected and acidified using $\mathrm{HNO}_{3}$. Acid digestion with $\mathrm{HNO}_{3}$ was performed as recommended by Baird et al. (2017):

138 Move $100 \mathrm{~mL}$ of well-mixed acid-preserved sample to a flask. Supply $5 \mathrm{~mL}$ concentrated HNO3 to a hood. To slow boiling and evaporation on a hot plate to the smallest volume possible (approximately 10 to $20 \mathrm{~mL}$ ) before precipitation, a reflux temperature of approximately $95^{\circ} \mathrm{C}$ was achieved. Heating was maintained, with concentrated $\mathrm{HNO} 3$ added as required, until a light-colored, transparent solution emerged.

142 Digested samples were filtered using glass fiber filters and then transferred to a $100-\mathrm{mL}$ volumetric flask.

143 Samples were cooled, diluted to the correct mark and mixed thoroughly. Standard solutions with different concentrations of each heavy metal were prepared to obtain a standard curve according to the linear regression method to obtain $R^{2}=0.997$. The curve with the related parameters was plotted automatically. An AAS9000 Flame/Graphite Furnace Integrated Atomic Absorption Spectrophotometer of Skyray Company was employed. IONEX Reference Standards from CHEM-LAB Company were used, which are certified under our ISO90001 Quality System and under the principles of GUM: 1995; ISO Guide 31:2000; ISO/IEC 17025. The certified value for each analyzed heavy metal was $1,000 \pm 4 \mu \mathrm{g} / \mathrm{ml}$, and the density was $\pm 0.0002 \mathrm{~g} / \mathrm{ml}$. The detection limit for 
the analyzed parameters was $0.001 \mathrm{mg} / \mathrm{L}$. Major pollutants such as lead, manganese, copper and cobalt, were analyzed in collected water samples.

\section{Chemicals}

Solvents used for extraction and analysis, such as acetonitrile, toluene, hexane, etc., were of HPLC grade and were Merck and Rankem products. Standards from Sigma Aldrich (ERS 009) for 16 PAH compounds were used. Silica gel with particle size 0.063 to $0.200 \mathrm{~mm}, 100$ to 200 mesh ASTM from Merck was used for the current work.

\section{Data Analysis and Mapping}

Data were statistically analyzed for correlation coefficients with SPSS (Version 24) with respect to means of water parameters in the study area. Surfer program V16 was used for map preparation.

\section{Cancer Risk Assessment}

PAHs are natural environmental contaminants that are thought to play a role in the development of human cancers. PAH compounds are metabolized enzymatically, and some of them are reactive. The CYP1A1, CYP1A2, CYP1B1, and CYP3A4 cytochrome P450 enzymes are important in the metabolism of polycyclic aromatic hydrocarbons (PAHs) (Walsh et al. 2013). PAHs undergo metabolic activation to diol-epoxides, which bind covalently to DNA. The DNA binding of activated PAHs is essential for the carcinogenic effect (Tarantini et al. 2011) and has been discovered in a variety of human tissues. A strong association between epidemiological studies has found a connection between PAH exposure and the number of PAH-DNA adducts (Jedrychowski et al. 2013).

For human exposure to chemicals (PAHs and heavy metals) in drinking water by way of overt ingestion and dermal absorption, the exposure dose through the ingestion pathway was measured and calculated by Equation 1, adapted from Exhibits 1-3, USEPA (2001),

$$
C D I=\frac{C_{W} \times I R \times E F \times E D \times C F}{B W \times A T}
$$

[Equation 1]

where CDI stands for chronic daily ingestion of chemicals ( $\mathrm{mg} \mathrm{kg1} \mathrm{d1),} \mathrm{Cw} \mathrm{stands} \mathrm{for} \mathrm{chemical} \mathrm{concentration} \mathrm{in}$ water ( $m g$ L-1), IR stands for ingestion rate of water ( $L$ day-1), EF stands for exposure frequency, 350 days year1, ED stands for exposure period (year), CF stands for conversion factor (1, $106 \mathrm{~kg} \mathrm{mg1),} \mathrm{BW} \mathrm{stands} \mathrm{for} \mathrm{body}$ weight in (kg), and AT stands for average time (day), 25,550 da.

The exposure dose of $\mathrm{B}(\mathrm{a}) \mathrm{P}$ through the dermal uptake pathway during bathing was calculated through Equations 2 and 3, which were obtained from 'Dermal Absorbed Dose per event for Organic Compounds - Water Contact', US EPA (2004).

$$
\left.D A_{\text {event }}=2 F A \times K_{p} \times C_{w} \sqrt{\frac{6 \tau_{\text {event }} \times t_{\text {event }}}{\pi}} \quad \text { \{provided tevent } \leq \mathrm{t}^{*}\right\} \quad \text { [Equation 2] }
$$


188 Where DAevent stands for dermal absorbed dose of B(a)P per event ( $\mathrm{mg} \mathrm{cm}^{-2}$-event), FA is the fraction absorbed water (dimensionless; for $B(a) P, F A=1$ ), $K_{p}$ represents the dermal permeability coefficient of $B(a) P$, the predicted value of $K_{p}$ for $B(a) P$ from the US EPA (2011) is $0.70\left(\mathrm{~cm} \mathrm{~h}^{-1}\right)$, tevent denotes the lag time per event $\left(\mathrm{h} \mathrm{event}^{-1}\right)$, for $B(a) P, \tau_{\text {event }}=2.69 \mathrm{~h} \mathrm{event}^{-1}$, tevent is the event duration, exposure time for shower and bathing (adults: $0.25 \mathrm{~h} / \mathrm{day}$; children: $0.33 \mathrm{~h} / \mathrm{day})$ is $\mathrm{h} \mathrm{event}^{-1}$, and $\mathrm{t}^{*}$ is the time to reach steady-state $(\mathrm{hr})=2.4$ Tevent.

DAD denotes daily chemical exposure via the dermal absorption pathway (mg kg1 d1), SA denotes exposed skin region in $\mathrm{cm} 2$, and $\mathrm{EV}$ denotes event frequency (1 bath per day; event day ${ }^{-1}$ ). The total carcinogenic risk for $\mathrm{B}(\mathrm{a}) \mathrm{P}$ present in consumed water for drinking is calculated by Equation 4:

where $R_{c}$ is the probability of developing cancer over a lifetime because of exposure to $B(a) P, S F_{i}$ is the ingestion cancer slope factor of $\mathrm{B}(\mathrm{a}) \mathrm{P}\left(\mathrm{mg} \mathrm{kg}^{-1} \mathrm{~d}^{-1}\right)$, which is expressed as the oral administrative dose, and $\mathrm{SF}_{\mathrm{d}}$ is the dermal cancer slope factor for $\mathrm{B}(\mathrm{a}) \mathrm{P}\left(\mathrm{mg} \mathrm{kg}^{-1} \mathrm{~d}^{-1}\right)$. All parameter values collected from citations are provided in Supplementary Table S2.

In the case of heavy metals, we used the 'Dermal Absorbed Dose Per Event for Inorganic Compounds - Water Contact' formula from the US EPA (2004). In this case,

The rest of the formulation for heavy metals is the same as that for B(a)P. The cancer slope factor for lead is $8.5 \times 10^{-3} \mathrm{mg} \mathrm{kg}^{-1} \mathrm{~d}^{-1}$ for ingestion and $0.073 \mathrm{mg} \mathrm{kg}^{-1} \mathrm{~d}^{-1}$ for dermal absorption (Mukherjee et al. 2020). $\mathrm{K}_{\mathrm{p}}$ of lead is $0.13 \times 10^{-3} \mathrm{~cm} \mathrm{~h}^{-1}$ (USEPA 2004). The rest of the detected heavy metals are not immediately carcinogenic and do not have well-defined cancer slope factor values (IRIS and US EPA 1988; MDH 2020; US EPA 2008). To assess which probability density functions have the greatest impact on the risk estimates, a sensitivity analysis was performed using Spearman rank order correlations. Oracle's Crystal Ball (11.1.2.4.600) program was used to complete the evaluation and sensitivity analysis. The same software created the 90 percent certainty dimension of risk evaluation. To ensure numerical stability, a total of 50,000 iterations were considered (Tarafdar et al. 2020). While the simulation is running, Crystal Ball determines sensitivity by calculating rank connection coefficients between each assumption and each prediction. Correlation coefficients show how often expectations and predictions are altered when they are combined. 

winter and summer seasons. The samples were tested for B(a)P, copper, lead, manganese and cobalt. The results and their concentrations in drinking water were compared with WHO guidelines for drinking purposes. The mean concentrations of all examined metals in the water assessed were not within acceptable limits (WHO 2011), posing a number of health risks.

\section{$B(a) P$ in Drinking water}

232

The levels of $B(a) P$ in the studied water samples were analyzed (Table 1 and Fig. 2 (a-d)) and showed seasonal fluctuations during the summer and winter seasons. $\mathrm{B}(\mathrm{a}) \mathrm{P}$, a carcinogenic PAH listed as a priority pollutant by the US EPA, was detected and ranged from 0.001 to $0.192 \mu \mathrm{g} \mathrm{L}^{-1}$ and 0.001 to $0.162 \mu \mathrm{g} \mathrm{L}^{-1}$ as measured by HPLC and ELISA methods, respectively. A significant correlation ( $\leq 0.01)$ was found between the two methods for B(a)P levels in drinking water samples; moreover, a significant correlation coefficient $(P \leq 0.01)$ was found between $\mathrm{B}(\mathrm{a}) \mathrm{P}$ measured by HPLC with $\mathrm{Cu}, \mathrm{Co}, \mathrm{Pb}$ and between $\mathrm{B}(\mathrm{a}) \mathrm{P}$ measured by ELISA kit with $\mathrm{Co}$ only, which indicates that HPLC is more sensitive for $\mathrm{B}(\mathrm{a}) \mathrm{P}$ measurement in drinking water.

$B(a) P$ levels were found to be high during the winter season compared with the summer season. Total means of $0.012 \mu \mathrm{g} \mathrm{L}^{-1}$ and $0.0469 \mu \mathrm{g} \mathrm{L}^{-1}$ were measured during the summer and winter seasons, respectively, when the ELISA method was used, while mean values of $0.01914 \mu \mathrm{g} \mathrm{L}^{-1}$ and $0.08585 \mu \mathrm{g} \mathrm{L^{-1 }}$ were recorded during the summer and winter seasons when the HPLC method was used. The highest mean levels were found in the liquid-liquid extraction method with HPLC during both seasons, which indicates the greater sensitivity of the method.

The statistical analysis indicated that there were significant correlations $(p \leq 0.01)$ between $\mathrm{B}(\mathrm{a}) \mathrm{P}$ levels between sampling sites (S2, S3, S7, S10, and S8) for the ELISA method and (S8, S2, S7, S3, S11, S10, S13) for the HPLC method and the $1^{\text {st }}$ sampling time. The highest correlation numbers were found between $B(a) P$ levels with the HPLC method and sampling sites.

The highest concentrations of B(a)P were recorded at sites S7 and S5, with levels of 0.192 and $0.122 \mu \mathrm{g}$ $\mathrm{L}^{-1}$ for HPLC and ELISA methods, respectively. The guideline value of WHO for benzo(a)pyrene in water used for drinking is $0.0007 \mathrm{mg} \mathrm{L}^{-1}\left(0.7 \mu \mathrm{g} \mathrm{L}^{-1}\right)$, and none of the samples surpassed this level; moreover, $\mathrm{B}(\mathrm{a}) \mathrm{P}$ levels exceeded the EPA limit in 2011 (0.01 ppb), particularly when the liquid-liquid extraction method with HPLC was used (Table 1).

Table 1 Benzo(a)pyrene mean levels in water samples $\left(\mu \mathrm{g} \mathrm{L}^{-1}\right)$ at the studied sites as determined by the liquidliquid extraction method and ELISA method.

\begin{tabular}{ccccc}
\hline site & B(a)P by liquid-liquid method $\left(\mu \mathrm{L} \mathrm{L}^{-1}\right)$ & \multicolumn{2}{c}{$\mathrm{B}(\mathrm{a}) \mathrm{P}$ by immunoassay (ELISA) method $\left(\mu \mathrm{L} \mathrm{L}^{-1}\right)$} \\
\hline & Summer & Winter & Summer & Winter \\
2 & 0.014 & 0.06 & 0.009 & 0.024 \\
3 & 0.004 & 0.047 & 0.003 & 0.005 \\
& 0.007 & 0.017 & 0.005 & 0.01
\end{tabular}




$\begin{array}{lllll}4 & 0.043 & 0.048 & 0.018 & 0.013 \\ 5 & 0.041 & 0.135 & 0.021 & 0.161 \\ 6 & 0.027 & 0.066 & 0.042 & 0.075 \\ 7 & 0.006 & 0.146 & 0.003 & 0.058 \\ 8 & 0.008 & 0.13 & 0.003 & 0.027 \\ 9 & 0.049 & 0.151 & 0.025 & 0.085 \\ 10 & 0.007 & 0.104 & 0.007 & 0.038 \\ 11 & 0.01 & 0.077 & 0.008 & 0.042 \\ 12 & 0.024 & 0.121 & 0.01 & 0.044 \\ 13 & 0.021 & 0.064 & 0.009 & 0.038\end{array}$

257

258

259

260

261

262

263

264

265

266

267

268

269

270

271

272

273

The recorded levels of B(a)P in the current study were lower than the levels recorded by Itodo et al. $2018\left(14.68 \mu \mathrm{g} \mathrm{L}^{-1}\right)$ in water systems in Nigeria and the results obtained by Chen $2004\left(0.18-0.35 \mu \mathrm{g} \mathrm{L}^{-1}\right)$ in the Cheng-Ching Lake of Taiwan and by Chen 2007, with a value of $0.156 \mu \mathrm{g} \mathrm{L}^{-1}$ for household drinking water in Taiwan.

Because of its close association with soil, there is little knowledge regarding B(a)P concentrations in groundwater, and B(a)P is not supposed to leach into groundwater. Between 2002 and 2012, 97.6\% of the 6,678 samples collected in distribution networks in Québec were below the detection level (range of $0.002-0.01 \mu \mathrm{g}$ $\left.\mathrm{L}^{-1}\right)$. The median value for the studied water was $0.004 \mu \mathrm{g} \mathrm{L}^{-1}$, with 20 results above $0.01 \mu \mathrm{g} \mathrm{L}^{-1}$. All results were below $0.01 \mu \mathrm{g} \mathrm{L}^{-1}$ in Nova Scotia (MDL $0.009-0.01 \mu \mathrm{g} \mathrm{L}^{-1}$ ) (FPTCDW 2015). Badawy and Emababy (2010) concluded that none of the drinking water samples of Egypt contain any B(a)P. Similar results were obtained by Mohammed et al. 2010 in drinking water of Ifraz water treatment plants of Erbil-Iraq.

High levels of benzo(a)pyrene can cause skin, lung, and bladder cancer in humans and animals, making it a likely cancer-causing agent (FPTC 2015). According to the International Agency for Research on Cancer (IARC), there is enough evidence to suggest that $\mathrm{B}(\mathrm{a}) \mathrm{P}$ is carcinogenic in laboratory animals and could be carcinogenic in humans, with the ability to cause cancer in experimental animals, as mentioned by Rajendran et al. (2013, 2014), due to the capability of B(a)P to induce tumors (Rajendran et al. 2008). 


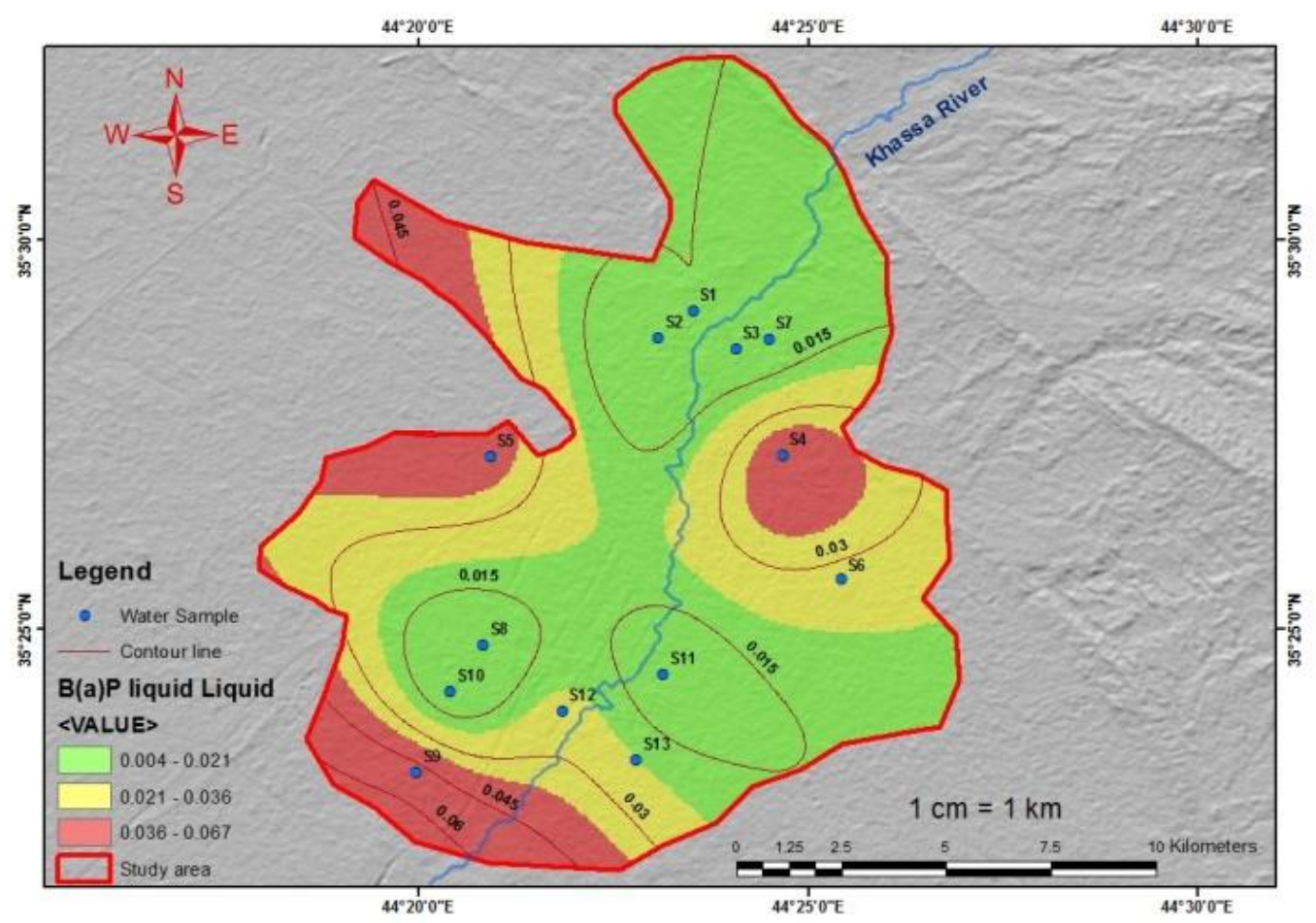

274

275

(a)

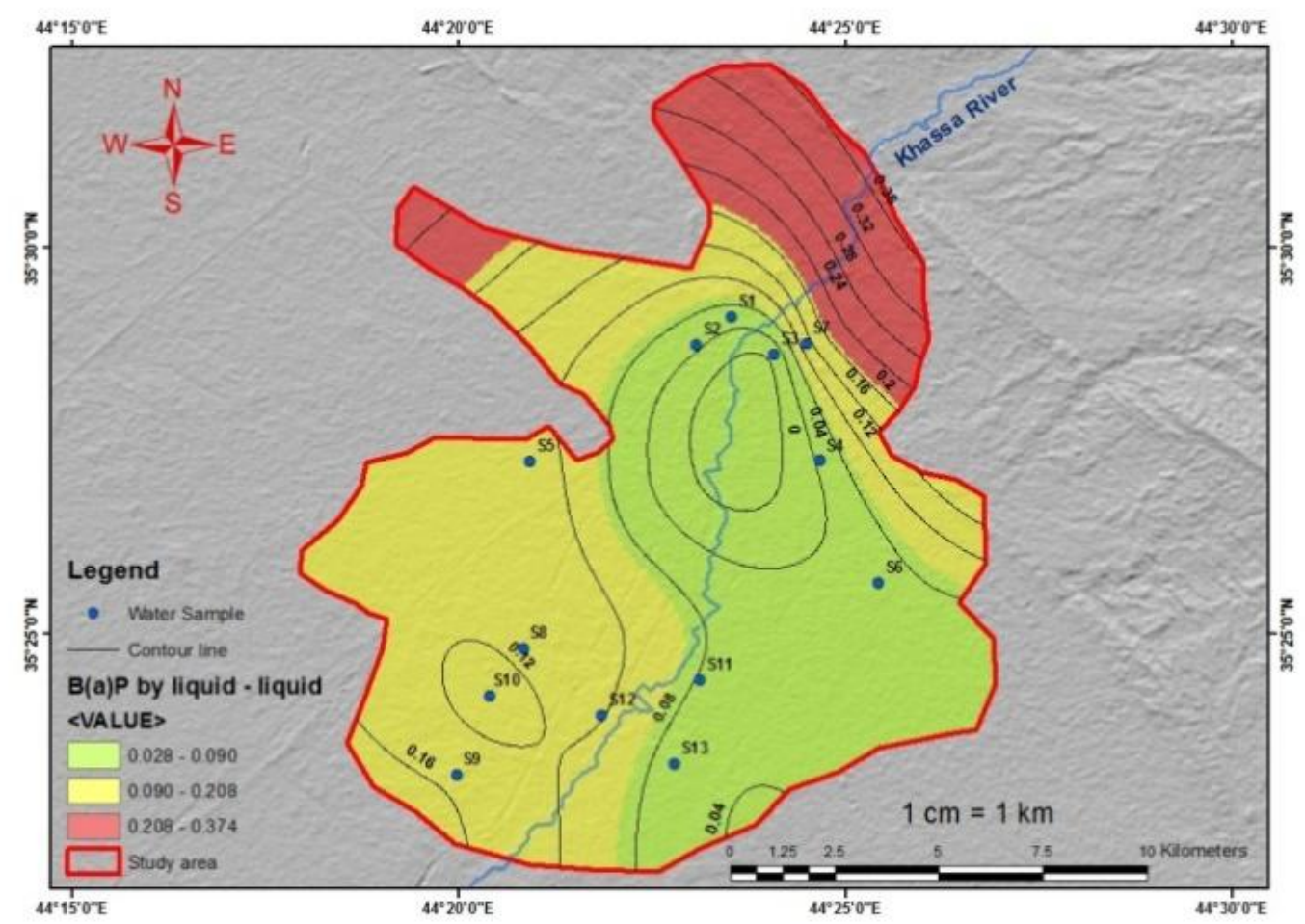

(b) 


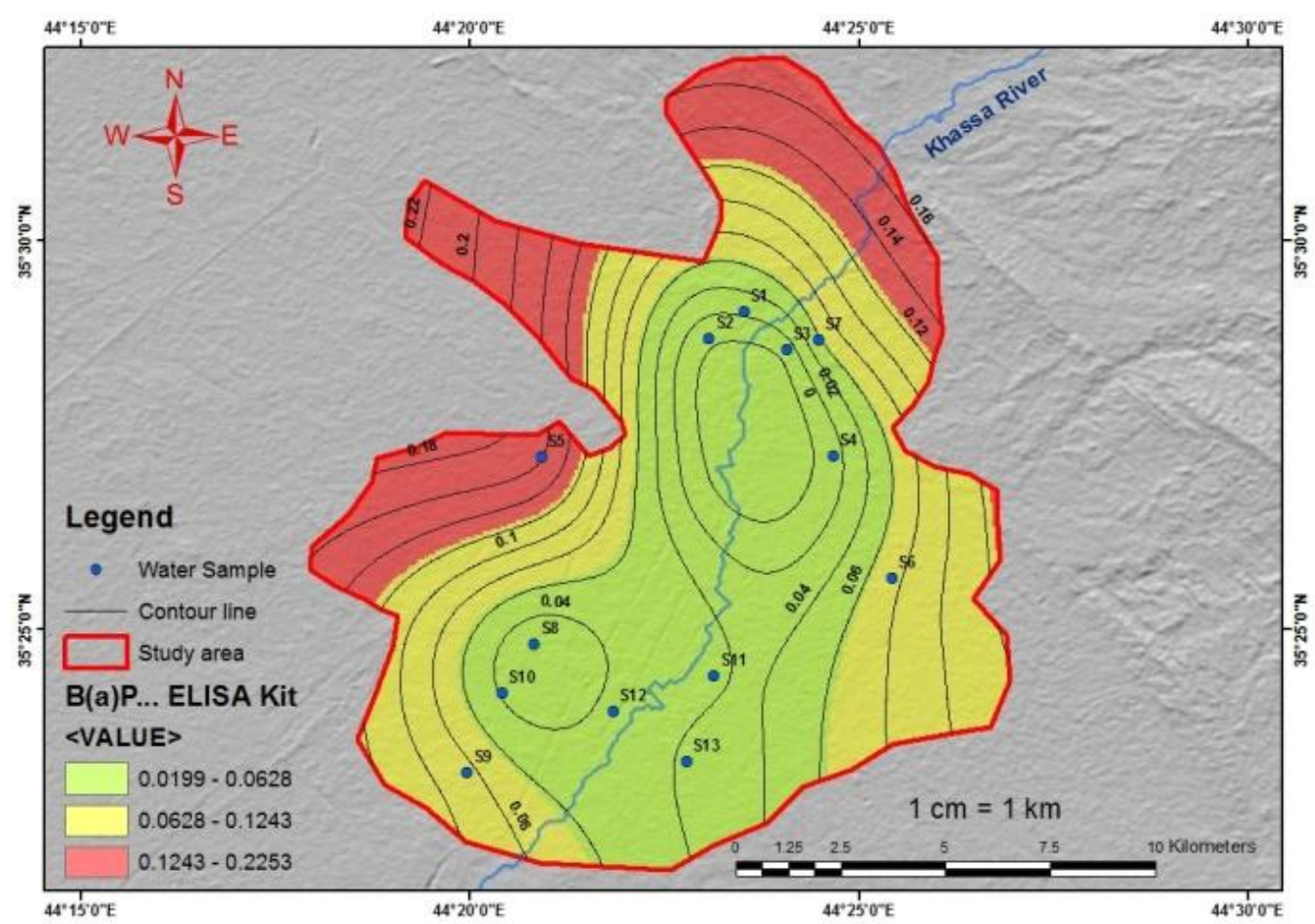

(c)

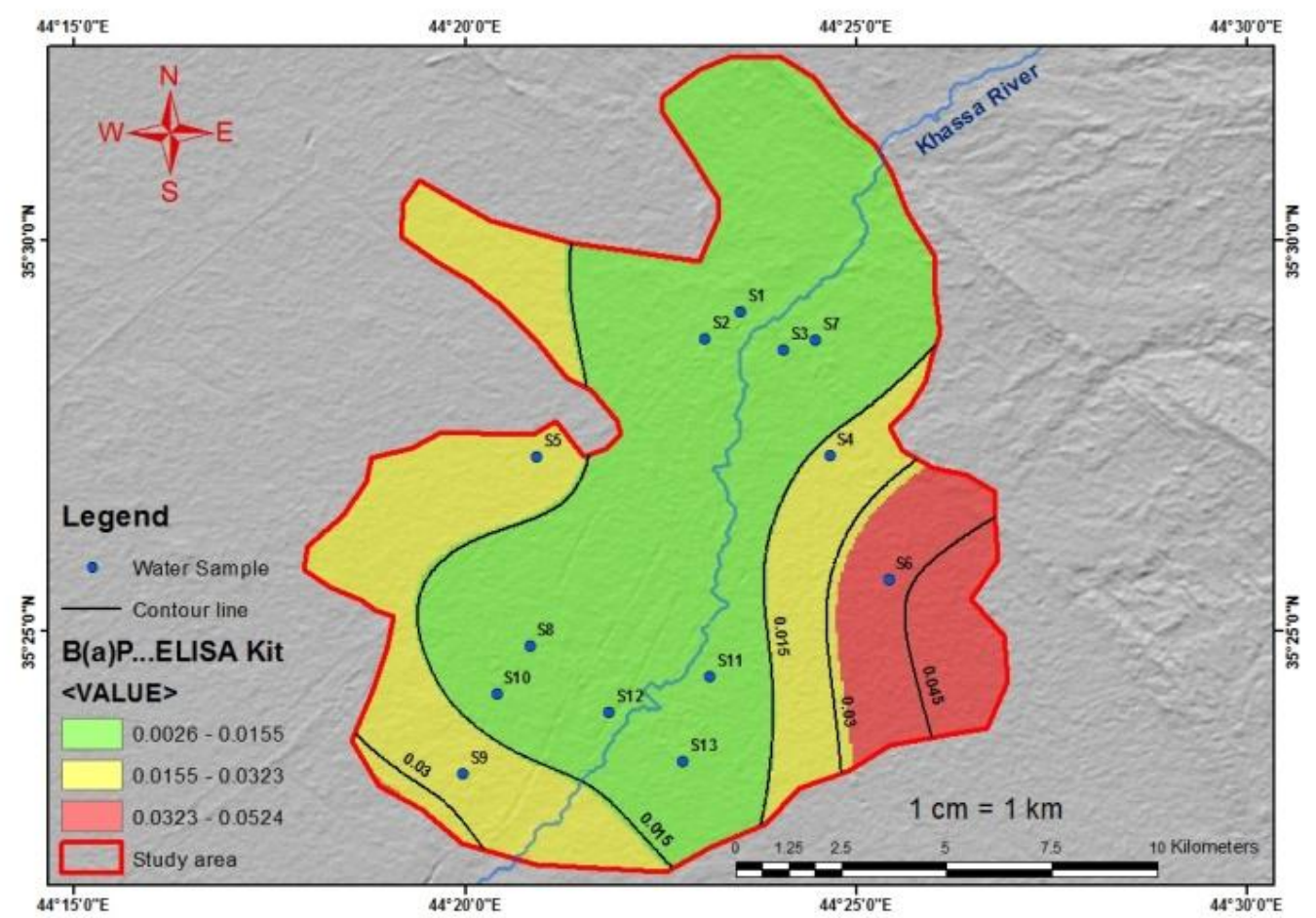




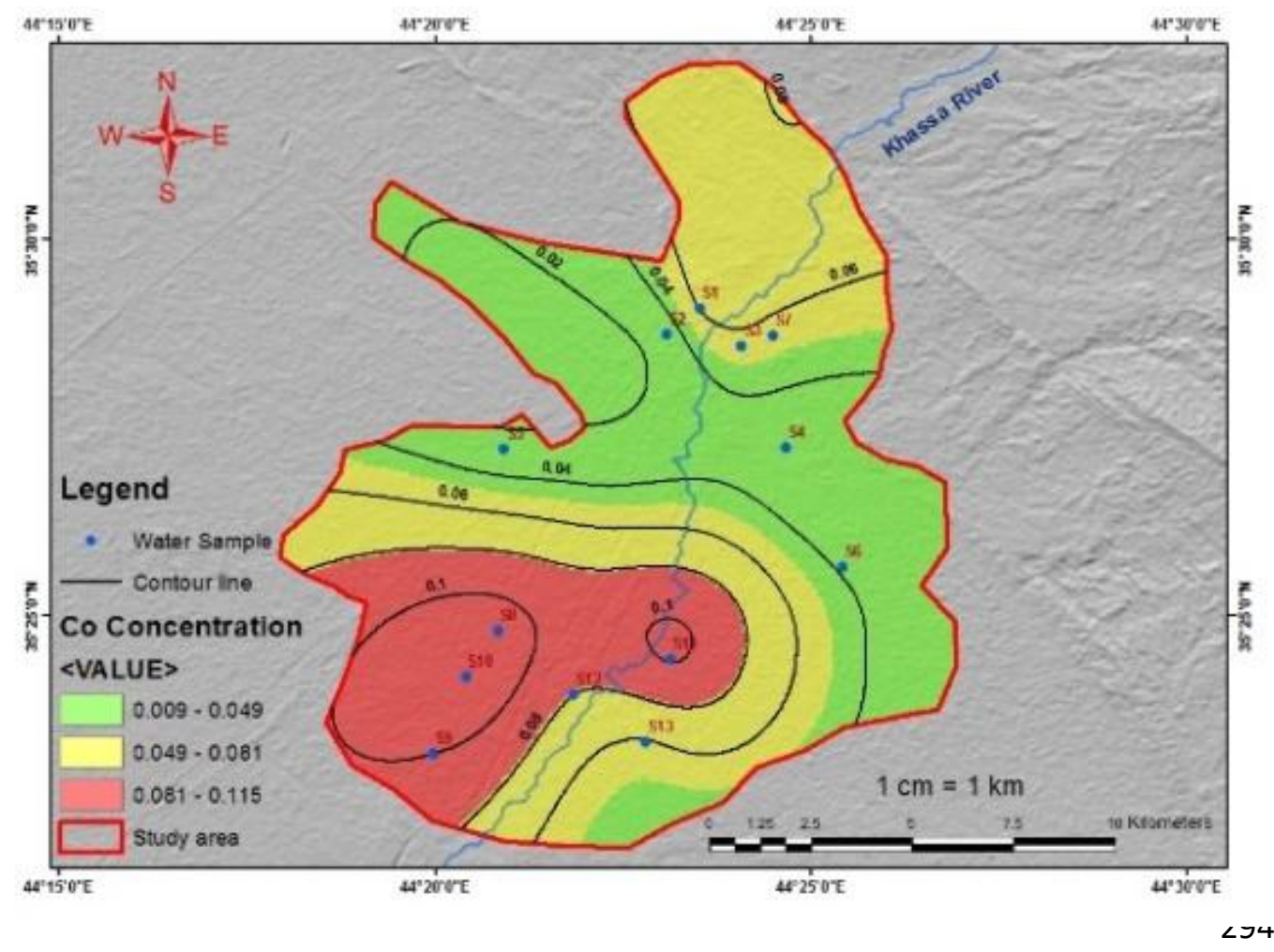

(e)

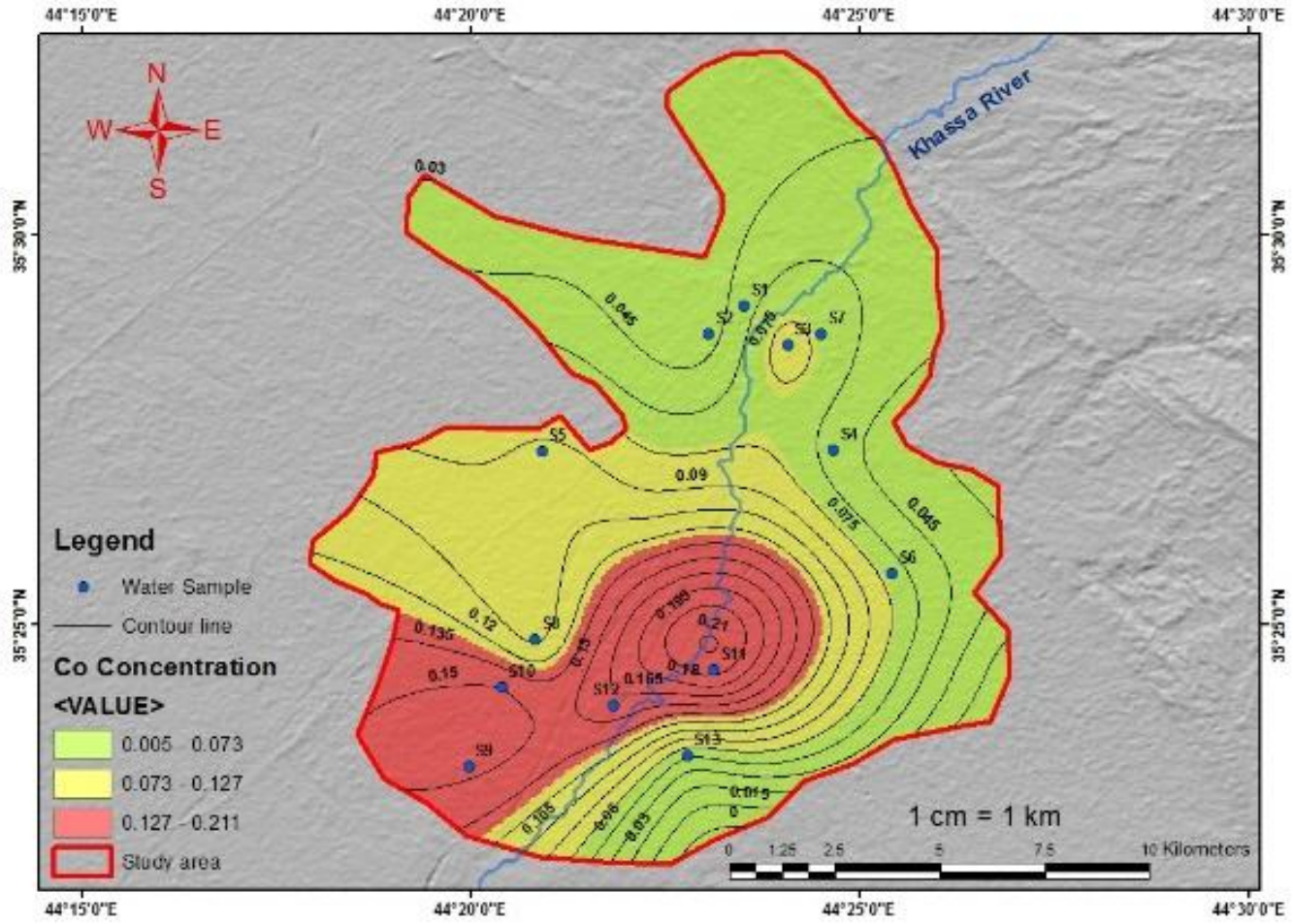




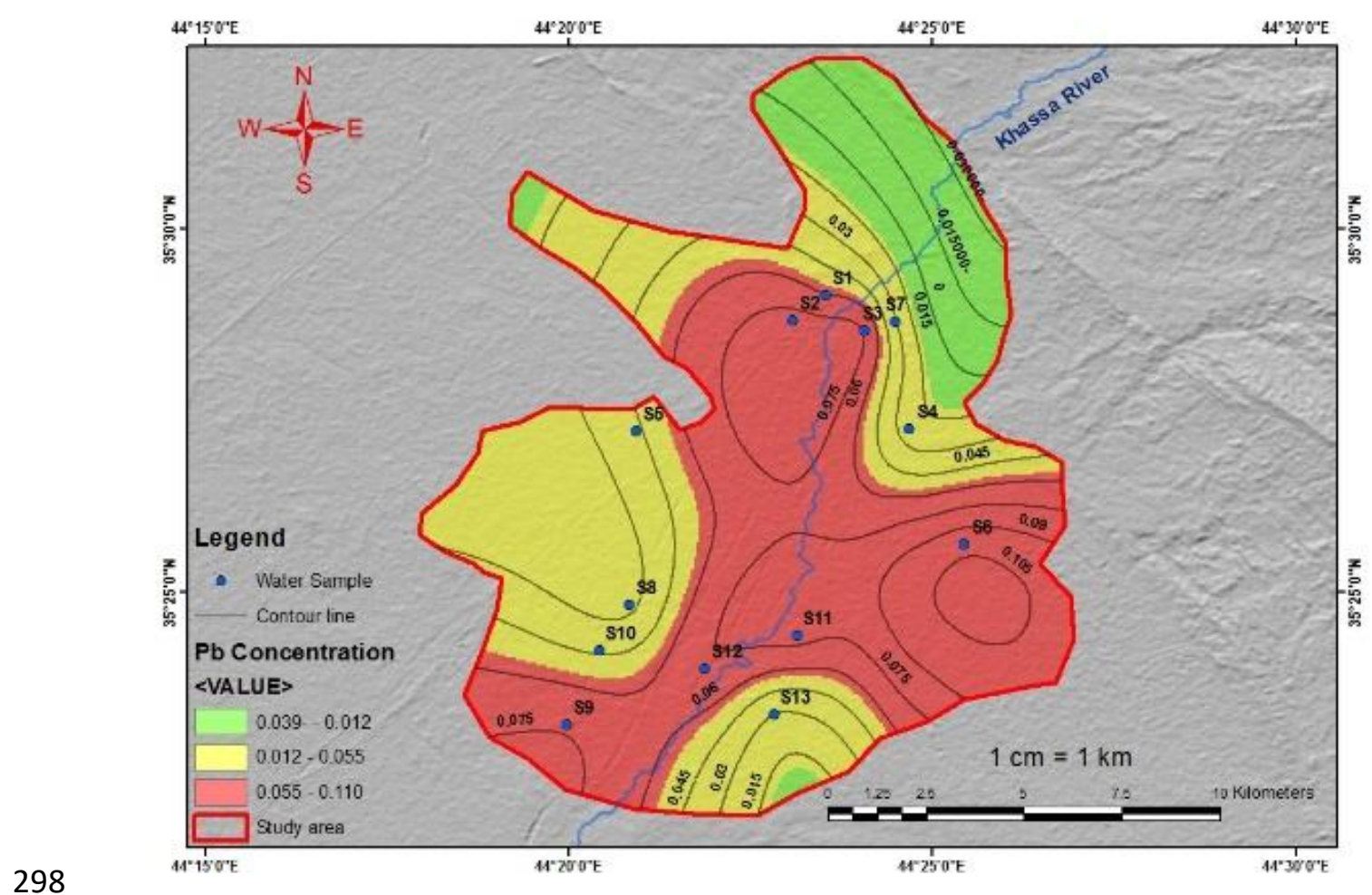

299 (g)

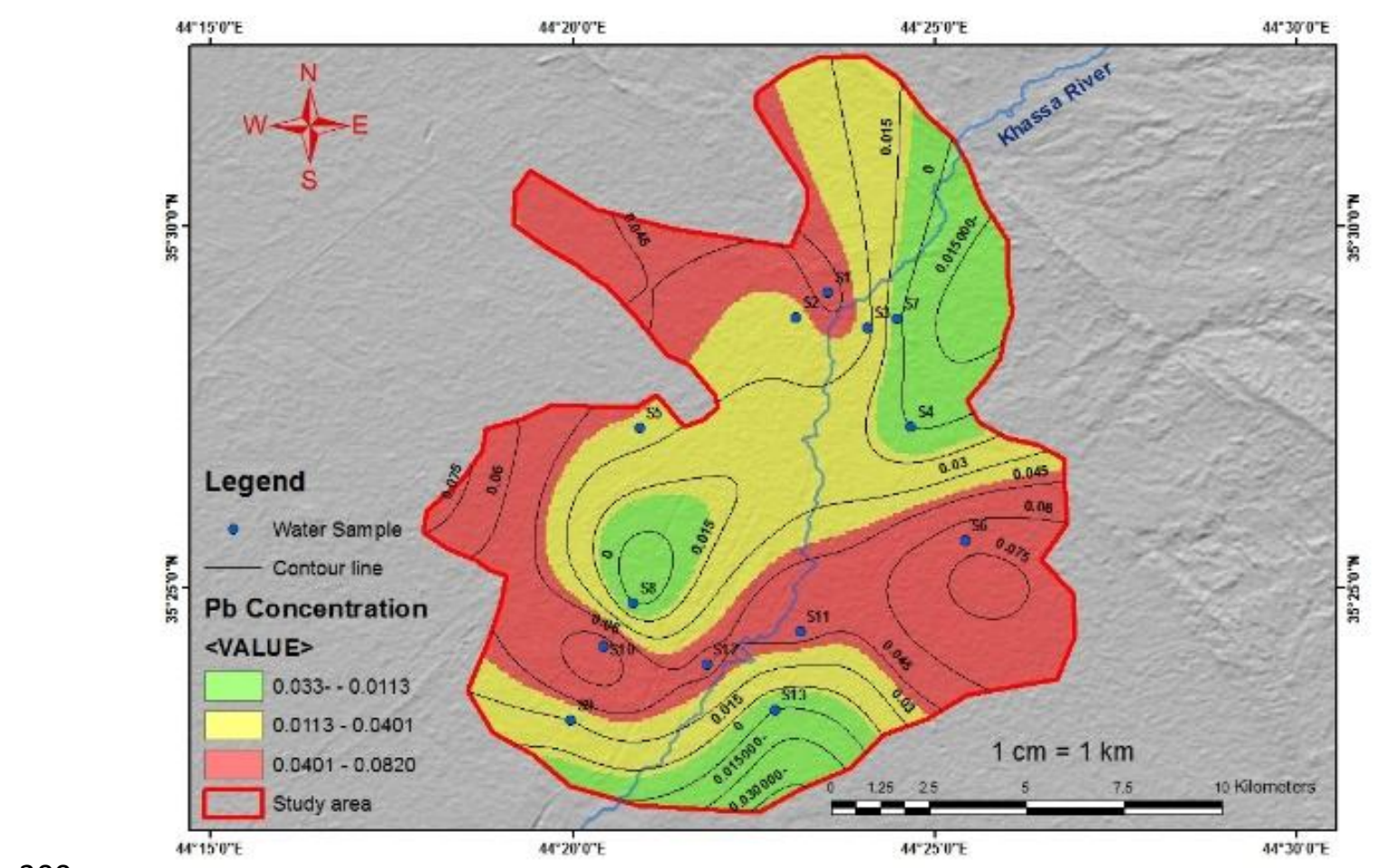




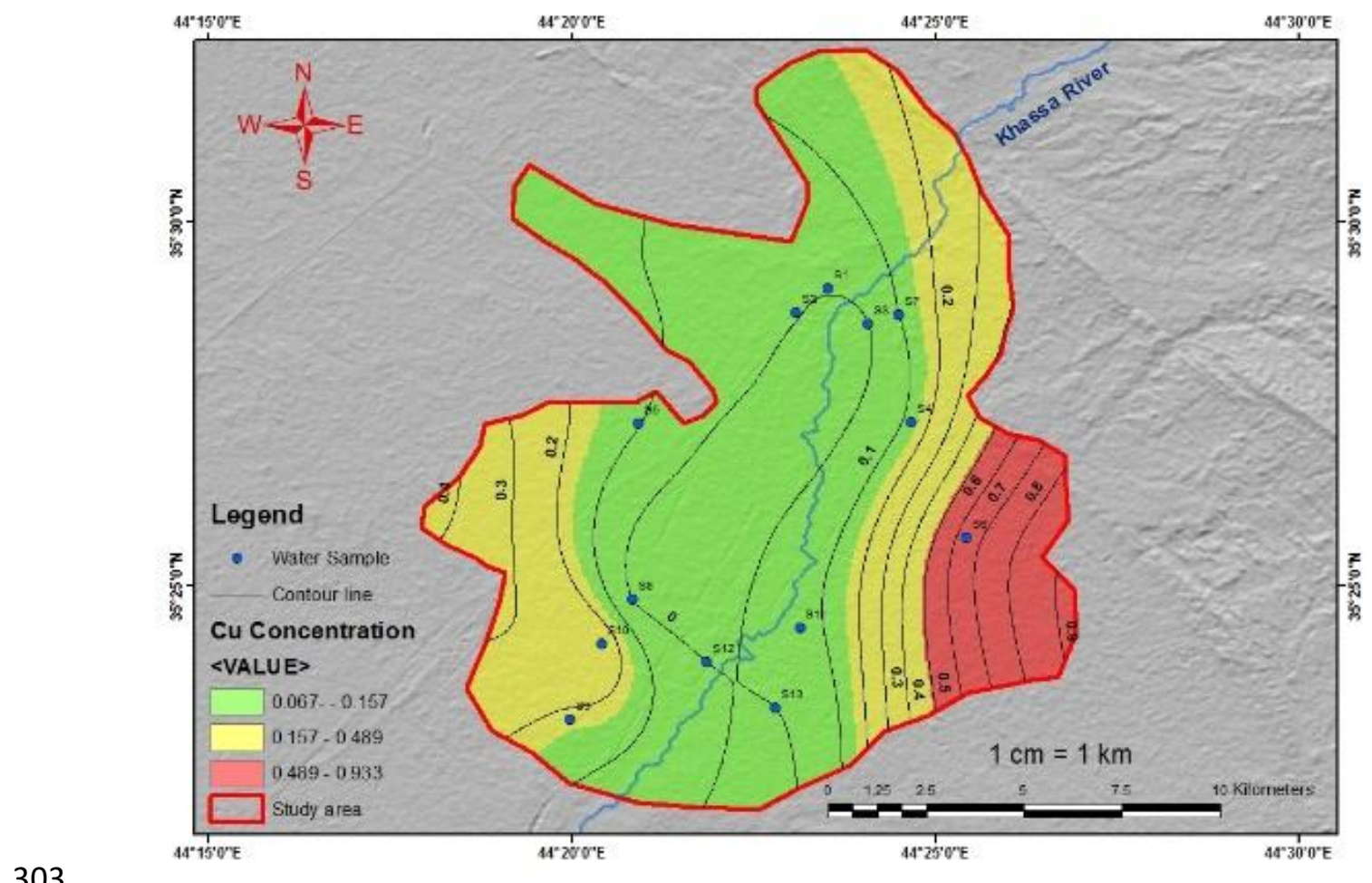

303

304

(i)

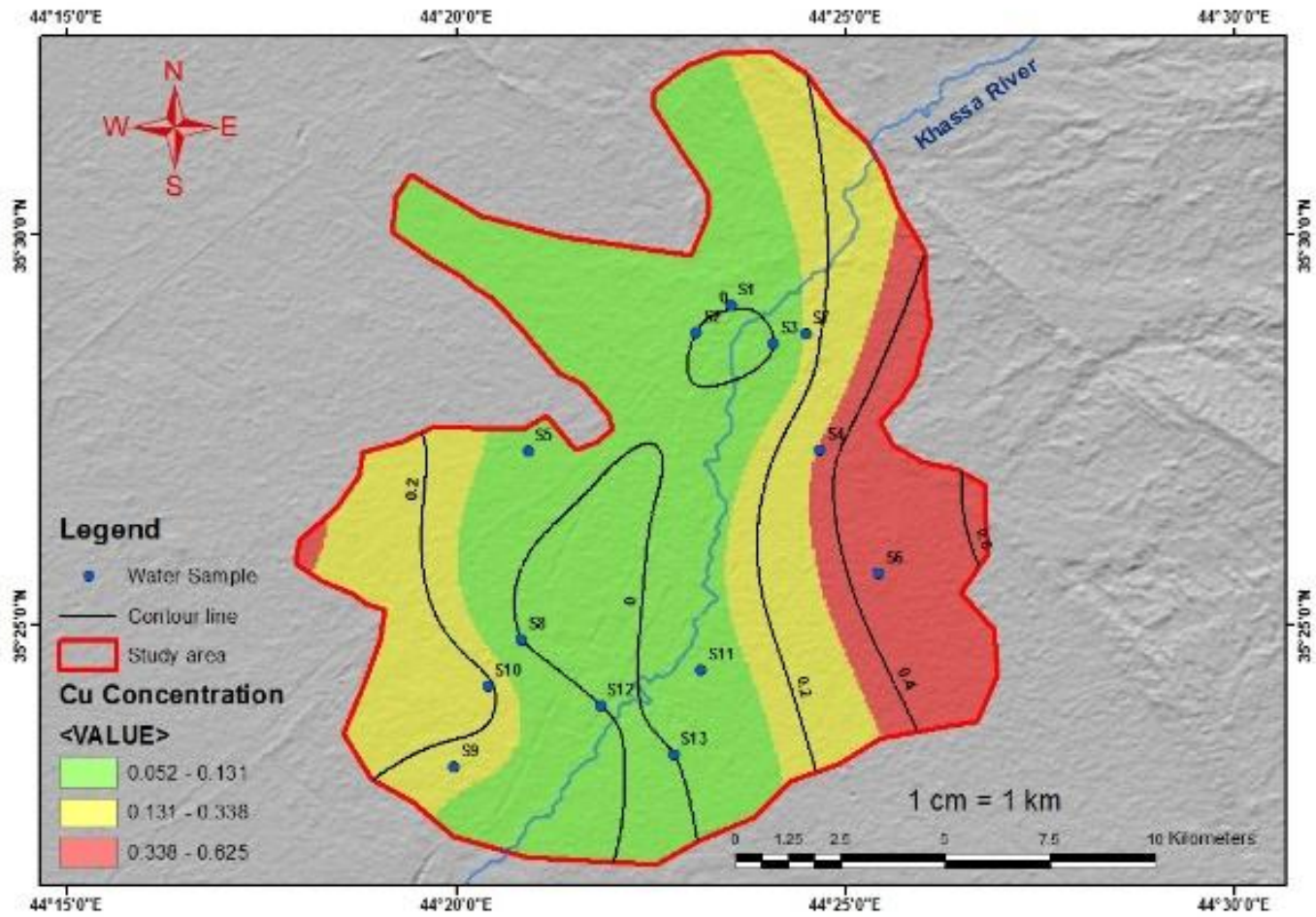

305

306

(j)

307 


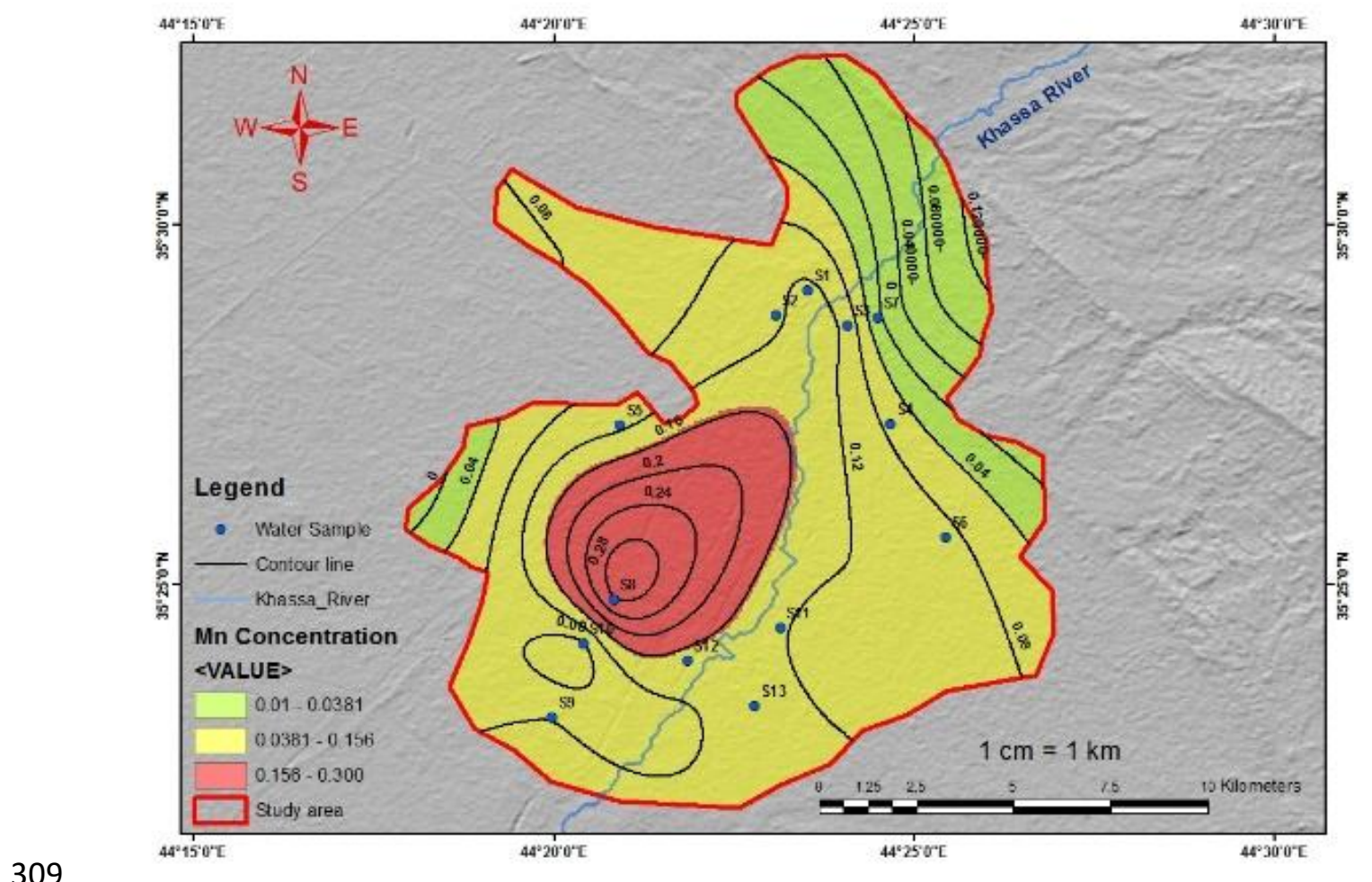

(k)

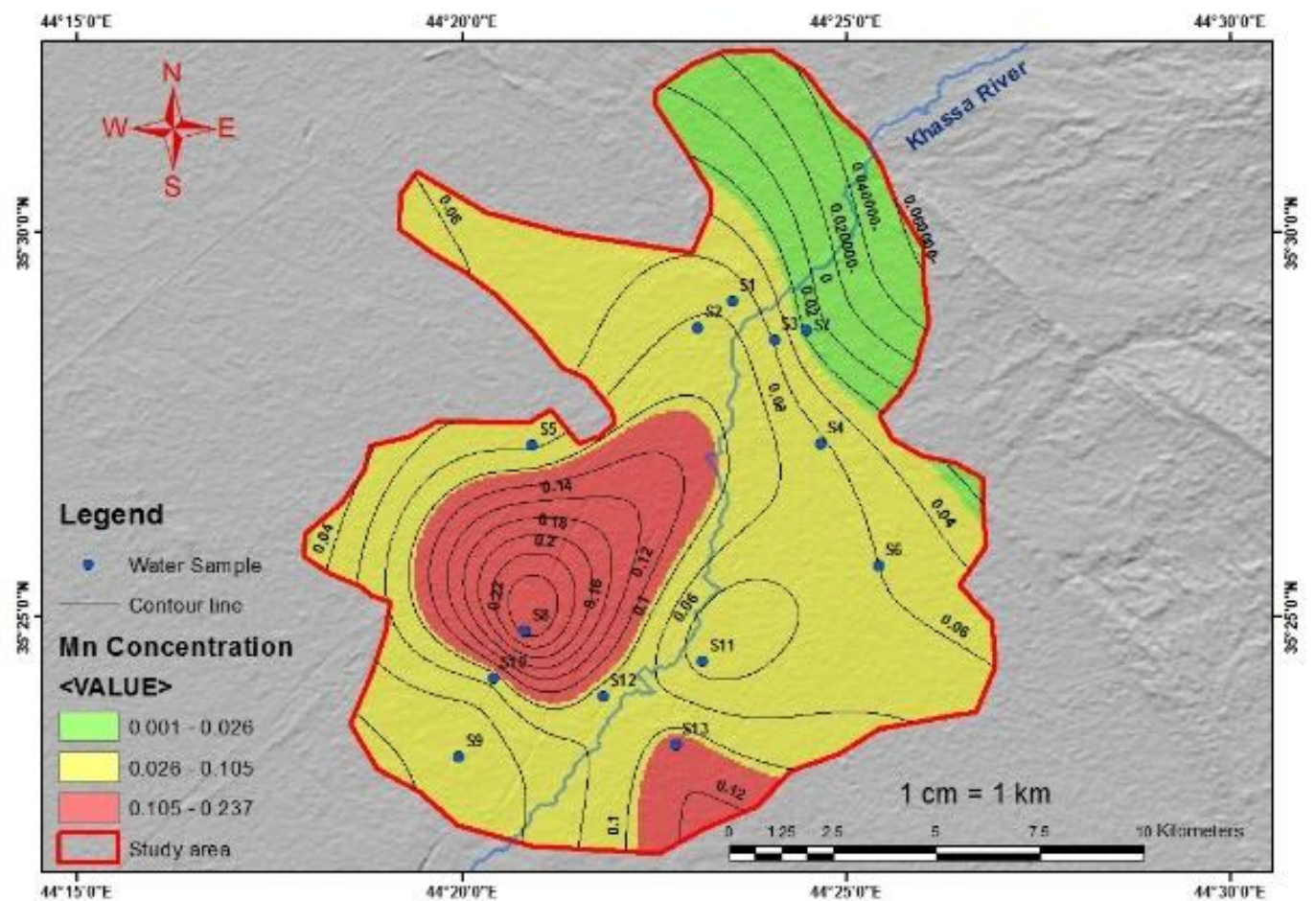

312 (I)

313 Fig. 2 Seasonal variation in (a-d) benzo(a)pyrene concentration determined by ( $a$ and $b$ ) liquid-liquid extraction 314 and ( $b$ and c) ELISA, where ( $a$ and c) correspond with wet and (b and d) with dry seasons. (e and f) Cobalt concentrations during wet and dry seasons. ( $g$ and $h$ ) Lead concentrations during wet and dry seasons. ( $i$ and $j)$ 
316 Copper concentrations during wet and dry seasons. ( $k$ and I) Manganese concentrations during wet and dry

317 seasons.

\section{Risk analysis}

319 The total B(a)P concentrations for each of the samples were calculated. The geometric mean concentration of $320 \mathrm{~B}(\mathrm{a}) \mathrm{P}$ in drinking water is $(0.014,2.300)$ in summer and $(0.073,1.877)$ in winter (geomean, geostdev in $\left.\mu g \mathrm{~L}^{-1}\right)$, 321 as determined by the liquid-liquid extraction method. For the ELISA extraction method, these concentrations 322 were $(0.008,2.296)$ in summer and $(0.034,2.465)$ in winter (geomean, geostdev in $\mu \mathrm{g} \mathrm{L}^{-1}$ ).

323 Bearing the different attributes of the two age groups, including ED, AF, BW, SA, EF, HR and so forth, as a primary 324 concern, the carcinogenic hazards for children and adults were determined based on eqs. [1]-[5]. At a 90\% 325 confidence level, Monte Carlo simulation was used to evaluate risk estimation for children and adults, and the 326 simulation results were published (for liquid-liquid extraction) and are depicted in Fig. 3. Risk simulations for ELISA extractions are depicted in Supplementary Data Fig. S1.

328

329

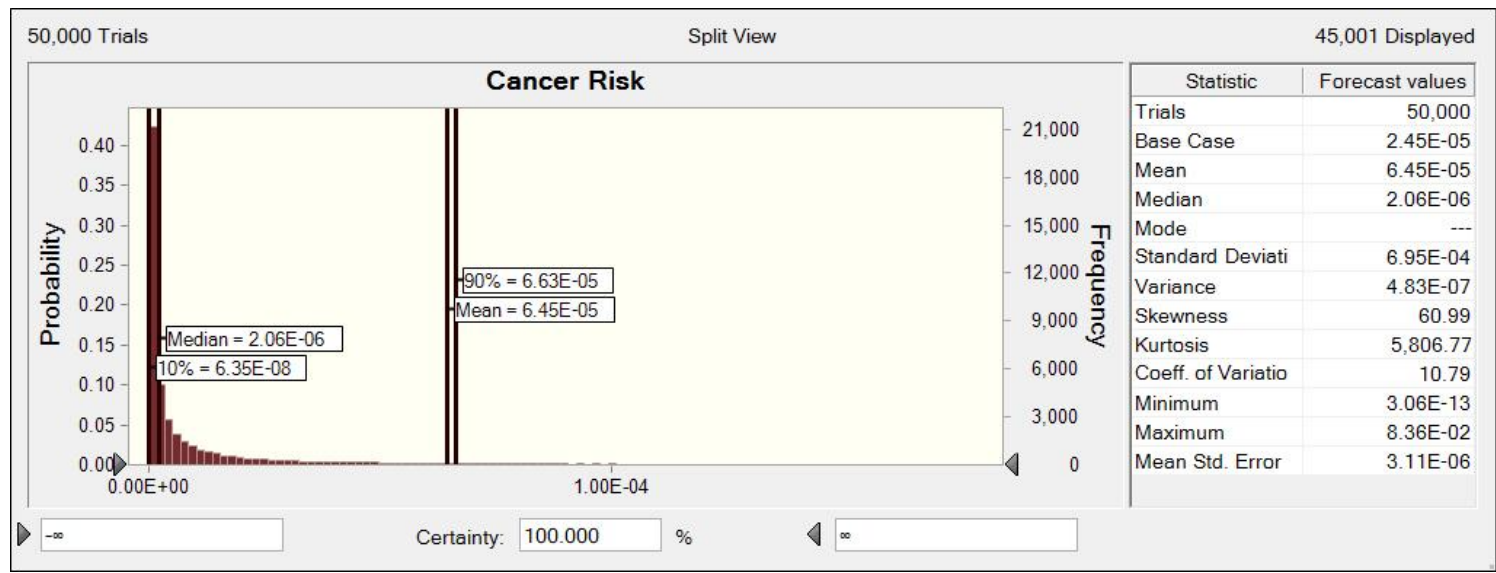

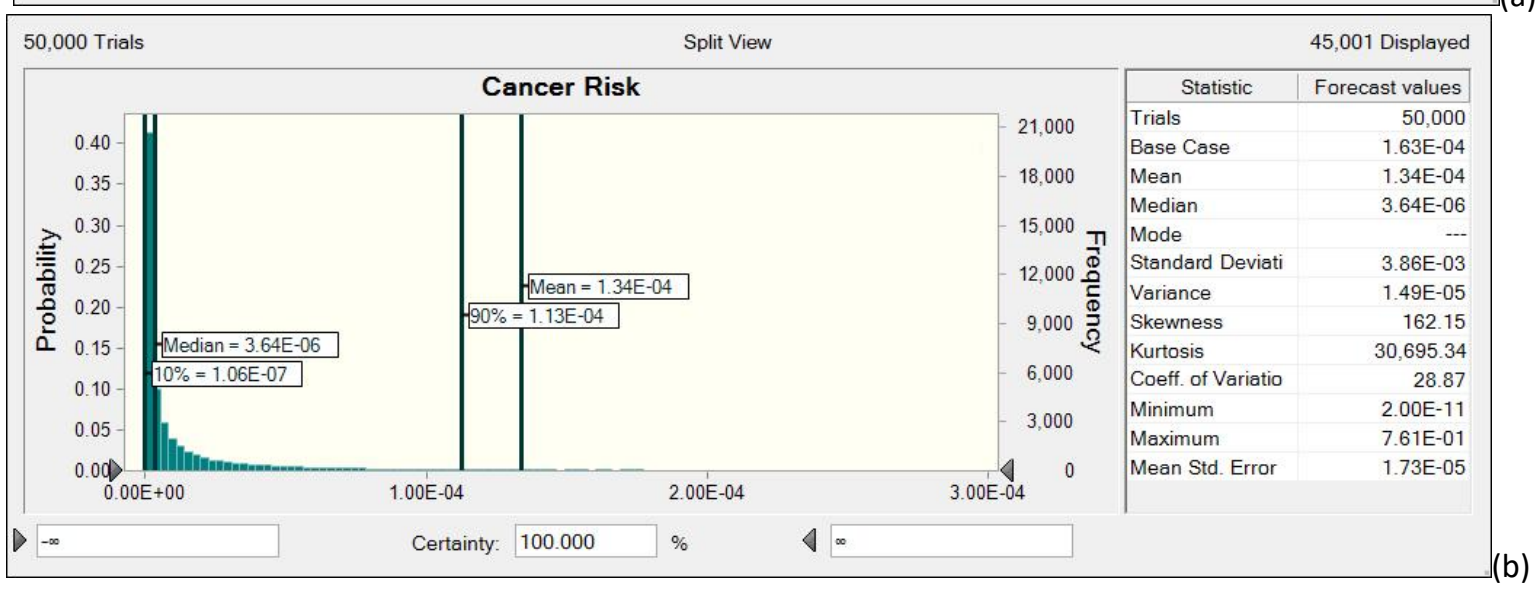




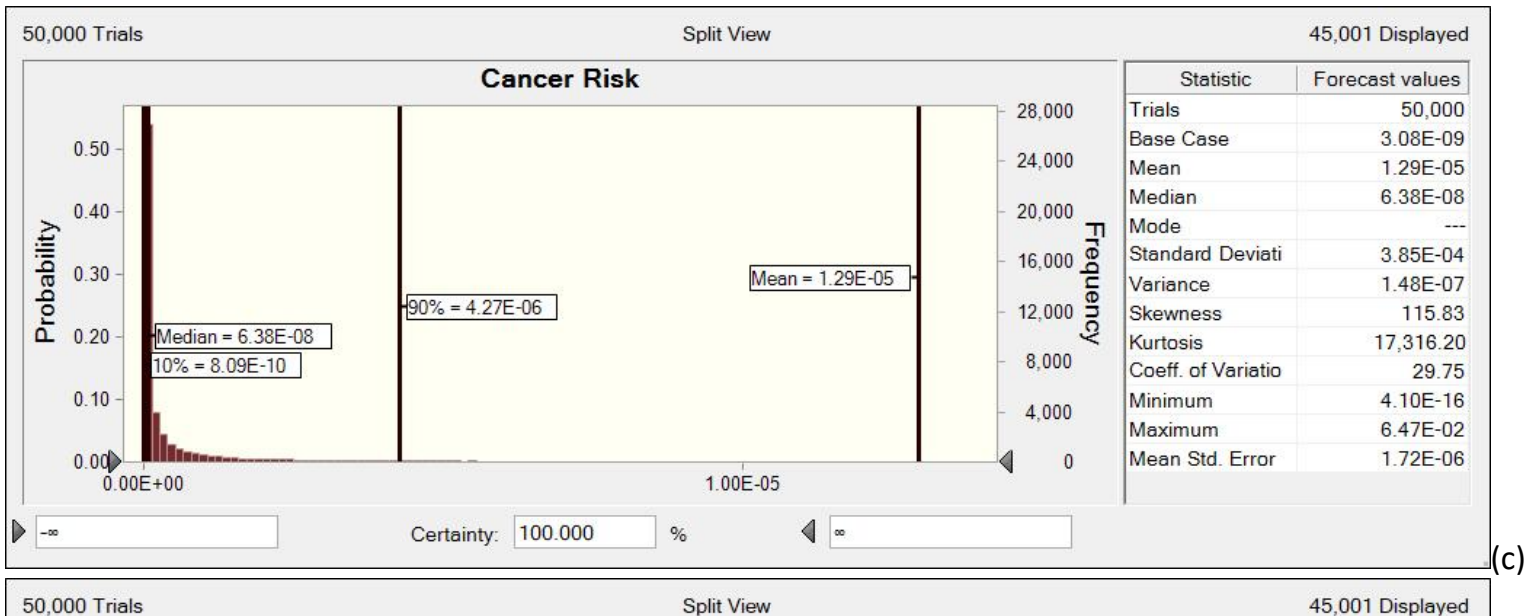

According to Fig. 3, the cancer risk from drinking water was $6.35 \mathrm{E}-08$ with a mean of $6.45 \mathrm{E}-05$ for children and ranged from $1.06 \mathrm{E}-07$ to $1.13 \mathrm{E}-04$ with a mean of 1.34E-04 for adults in the winter season, according to Monte Carlo simulation. For infants, the cancer risk from drinking water ranged from 8.09E-010 to 7.39E-06, with a mean of 1.29E-05, and for adults, the risk ranged from 1.41E-09 to 7.39E-06, with a mean of 1.58E-05.

$\mathrm{B}(\mathrm{a}) \mathrm{P}$ was listed as carcinogenic to animals and humans by the Agency for Research on Cancer (1987) and the US Environmental Protection Agency (1984), which agreed with results obtained by Chen et al.., (2020) (benzo(a)pyrene $(\mathrm{B}(\mathrm{a}) \mathrm{P})>$ anthracene $($ Ant) > pyrene $($ Pye) > phenanthrene (Phe) > fluoranthene (Flua) > acenaphthene (Ace) > fluorene (Flu) > naphthalene (Nap).). The results of the total risk assessment in the current study had values of 4.27E-06 in children to 7.39E-06 in adults during the wet season and 6.63E-05 and 1.13E-04 in children and adults during the dry season (for results obtained by the HPLC method), with a total mean of 4.77E-05, which agreed with the results obtained by Yan et al. 2018 in southern China with a level of $2 * 10^{-5}$ and the results obtained by Karyab et al. (2016) in Tehran, Iran, with a mean value of $8.81 * 10^{-05}$, and were lower than the results of Rajasekhar et al. 2018, with values of $3.76 * 10^{-3}$ in adults and $6.77 * 10^{-4}$ in children.

The results of the total risk assessment in the current study include values of 4.27E-06 in children to 7.39E-06 in adults during the wet season and 6.63E-05 and 1.13E-04 in children and adults during the dry season (for results obtained by the HPLC method). 
Moreover, lower carcinogenic risks were obtained when an ELISA kit was used, and all results for total risks (oral and skin exposure) were lower, which supports our opinion that the HPLC method is more sensitive and accurate for B(a)P measurement and that more variations exist between the summer and winter seasons. During both seasons, the mean values of total risk (oral and dermal) in both children and adults were found to be within the US EPA permissible risk range of $1 \mathrm{E}-04$ to $1 \mathrm{E}-06$. Children were found to be at lower risk than adults when subject to contamination through dermal and oral uptake because children have higher growth rates than adults if compared with body weight, but the duration of exposure and ingestion rate in adults are higher: this is in agreement with results of Rajasekhar et al. (2018), where adults were exposed to higher risk than children. For the purpose of comparing actual risk, the US EPA established a reasonable risk of 10E-06 (more conservative). In previous studies, however, values of 10E-04 and 10E-05 were also considered for permissible risk (Pan et al. 2015; Saha et al. 2017). The risk of direct water ingestion is found to be acceptable in both children and adults when a value of 10E-04 is used as a screening value. The risk calculated from heavy metal concentration (lead) is almost negligible in comparison with the risk from $\mathrm{B}(\mathrm{a}) \mathrm{P}$. The $90 \%$ percent cancer risk for children is 2.46E-09; for adults, the value is $3.83 \mathrm{E}-09$ in summer. In winter, the $90 \%$ cancer risk for children is 5.53E-09, and for adults, it is 9.08E-09 in summer (Supplementary data Fig. S2). These results do not heavily contribute to the total risk calculated for B(a)P. However, follow-up studies are needed to determine concentrations of heavily carcinogenic heavy metals such as arsenic and cadmium. According to the IARC (International Agency for Research on Cancer), there is sufficient evidence to conclude that $\mathrm{B}(\mathrm{a}) \mathrm{P}$ is carcinogenic in laboratory animals and may be carcinogenic in humans, with the potential to cause lung cancer in experimental animals, as stated by Rajendran et al. in 2013 and 2014 (Rajendran et al. 2008). $\mathrm{B}(\mathrm{a}) \mathrm{P}$ is a carcinogenic product produced through a three-step metabolic activation process.

\section{Uncertainty and Sensitivity}

374 To assess the variability and ambiguity of the parameters in the risk pathway with respect to the risk assessment, a quantitative analysis of the sensitivity of the risk parameters was performed. The results of the sensitivity analysis of cancer risk assessment are presented as tornado plots, which depict the Spearman rank order correlation coefficients on a rank scale (Fig. 4).

$$
\text { Rank Correlation View }
$$

\section{Sensitivity: Cancer Risk}

\begin{tabular}{|c|c|c|c|c|c|}
\hline \multicolumn{6}{|c|}{ Rank Correlation View } \\
\hline \multicolumn{6}{|c|}{ Sensitivity: Cancer Risk } \\
\hline \multirow[b]{2}{*}{$\mathrm{Cw}$} & 0.00 & 0.20 & 0.40 & 0.60 & 0.80 \\
\hline & & \multicolumn{4}{|c|}{0.94} \\
\hline ED & & 0.27 & & & \\
\hline BW & -0.05 & & & & \\
\hline SA & -0.01 & & & & \\
\hline $\mathbb{R}$ & o.po & & & & \\
\hline $\mathrm{SFi}$ & 0.00 & & & & \\
\hline
\end{tabular}




\section{Rank Correlation View}

380

381

382

383

384

385

386

387

388

389

390

391

392

393

394

395

396

397

398

399

400

401

402

403

404

405

406

407

408

Sensitivity: Cancer Risk

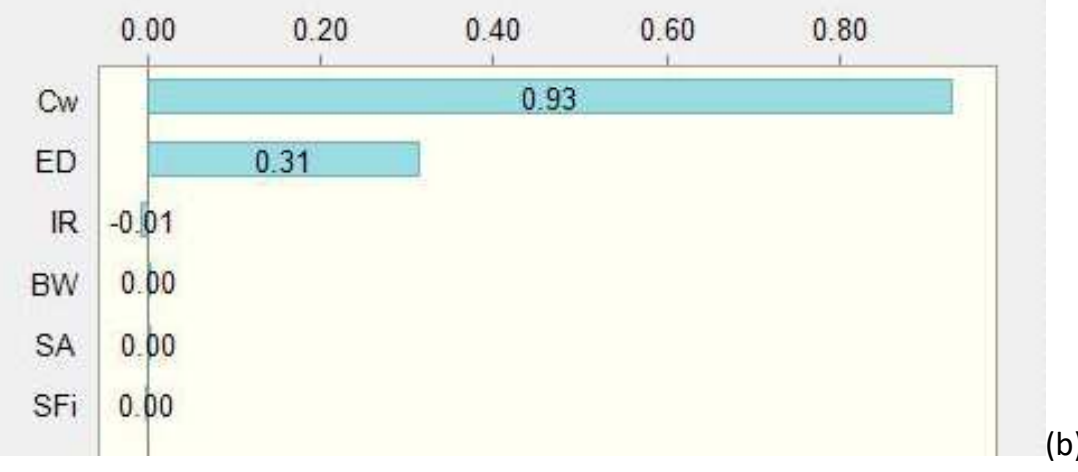

Fig. 4 Sensitivity analysis of cancer risk parameters in two groups: children (a) and adults (b).

Variations in $\mathrm{B}(\mathrm{a}) \mathrm{P}(\mathrm{Cw})$ concentrations in various sampling sites appear to contribute the most to variation in overall cancer risk, followed by exposure length (ED). The key cause for consistently higher cancer risks in adults is ED, which is 11 years for children and 52 years for adults. ED is followed by body weight (BW) for children and ingestion rate of water (IR) for adults. This result is consistent with previous studies (Tarafdar et al. 2018; Tarafdar and Sinha 2017a). The accuracy of the evaluation can be improved by using a more accurate and welldefined probability distribution of ED, IR, and BW.

Uncertainties/vulnerabilities in health hazard assessments are unavoidable due to a lack of appropriate knowledge regarding the investigation's boundaries (Tarafdar and Sinha 2018a). However, we have utilized Monte Carlo simulation to limit vulnerability, although some of it still exists in the risk evaluation measure (Tarafdar and Sinha, 2017b, 2018b). The probable exposure parameters for water ingestion rate (IR), skin surface area (SA) and body weight (BW) were directly calculated from US EPA suggested values. These probably will not be a precise match to the Iraqi situation, making them uncertain parameters of the investigation. Precise studies are also needed for more refined definitions of the parameters identified by sensitivity analysis.

\section{Heavy metals in drinking water}

Cobalt concentrations throughout the entire study period ranged between 0.01 and $0.28 \mathrm{mg} \mathrm{L}^{-1}$, with a total mean value of $0.0817 \mathrm{mg} \mathrm{L}^{-1}$. The lowest value of $\mathrm{Co}\left(0.01 \mathrm{mg} \mathrm{L}^{-1}\right)$ was recorded at site 2 during the winter season, while the maximum value $\left(0.28 \mathrm{mg} \mathrm{L}^{-1}\right)$ was recorded at site 12 during the winter season (Table 2). The Co results indicated that there was a significant correlation between $\mathrm{Co}$ and $\mathrm{Pb}$ and $\mathrm{B}(\mathrm{a}) \mathrm{P}$ for the studied water samples in Kirkuk city. These similarities show that the geological structure and composition of rocks represent the sources of heavy metals and govern chemical parameters in water samples (Issa and Alshatteri 2018).

The results of the current study were higher than the results obtained by Malkani et al. 2019 for ground water systems in India, with levels ranging between 0.128 and $0.159 \mathrm{ppb}$.

The cobalt concentration was found to be above the US EPA (2008) guideline $\left(0.1 \mathrm{mg} \mathrm{L}^{-1}\right)$ at 3 sites during the summer season and 4 sites during the winter season, with mean values ranging from 0.027 to 0.114 
and 0.04 to $0.2 \mathrm{mg} \mathrm{L}^{-1}$, respectively. Twenty-one percent and $28 \%$ of sampling sites during the summer and winter seasons, respectively, did not comply with the US EPA guidelines $(0.1 \mathrm{mg}$ L) for the maximum admissible limits of cobalt in drinking water (Table 2).

Data for lead concentration showed significant differences $(P \leq 0.05)$ with $\mathrm{Cu}$ and $\mathrm{Co}$ and with $\mathrm{B}(\mathrm{a}) \mathrm{P}(\mathrm{P} \leq$ 0.01 ) between the studied sampling sites and date of sampling, with an overall mean value of $0.04542 \mathrm{mg} \mathrm{L}^{-1}$. Lead levels ranged between 0 to 0.08 and 0.01 to $0.11 \mathrm{mg} \mathrm{L}^{-1}$ during the summer and winter seasons, respectively. The results of the current study exceed the WHO guidelines $\left(10 \mu \mathrm{g} \mathrm{L}^{-1}\right)$ for drinking water in most samples collected, although $\mathrm{Pb}$ levels at some sites are below detection limits and agree with results obtained by Mebrahtu* and Zerabruk (2011), with values ranging between $<0.005$ and $1.347 \mathrm{mg} \mathrm{L}^{-1}$. High levels of lead in drinking water can permanently damage the central nervous system, brain, and kidneys (Hanaa et al. 2000).

During the winter season, the highest level of $\mathrm{Pb}(0.11 \mathrm{mg} \mathrm{L}-1)$ was found in drinking water samples 2 , 6 , and 9, and the lowest level of BDL was found in drinking water samples 4, 8, and 13 . More than $10 \%$ of the samples tested contained levels of lead that exceeded the WHO (2011) guidelines, and the maximum allowable level of lead in drinking water was $10 \mu \mathrm{g} \mathrm{L}^{-1}$. The results of the current study agreed with those obtained by EhiEromosele and Okiei (2012), with levels ranging from 0.020 to $0.215 \mathrm{mg} \mathrm{L}^{-1}$.

The unusually high level of lead in tap water might be due to fittings made from brass, runoff from domestic use, and industrial wastes (such as improper disposal of acid lead batteries and wind-blown dust), and agricultural waste might be the main source of $\mathrm{Pb}$ pollution in the lesser Zab River which was not removed by the Kirkuk water treatment plant or picked up by weathering and leaching of lead from waste rocks dumps (Rajkovic et al. 2008). The levels are affected by temperature, acidity, water hardness, the length of pipes and the time that water is left to stand in the pipes (stagnation) before it is drawn off (Ehi-Eromosele and Okiei 2012): moreover, lower results were obtained by Alrakabi and Ramadan (2020) in drinking water of Baghdad city, with levels ranging from 0 to $0.04 \mathrm{mg} \mathrm{L}^{-1}$, yet still higher than the WHO guideline. BDL results recorded by Issa and Alshatt (2018) from drinking water systems of the Garmian area in the Kurdistan Region of Iraq were lower than the results of Ibrahim et al. 2018 for surface and groundwater of Samarra City, Central Iraq, with levels ranging from 0.176 to $1.133 \mathrm{mg} \mathrm{L}^{-1}$, and those of Aleseyyed et al. (2018) on ground water systems in urban and rural areas of Hamadan Province in Iran, with levels ranging from 2.636 to 40.155 ppb. Lead and its compounds can be present in pipes that transport water, contaminating the water (Brochin et al. 2008). Ionic toxicity occurs mainly due to the ability of lead metal ions to replace other divalent cations, such as $\mathrm{Ca}^{2+}, \mathrm{Mg}^{2+}, \mathrm{Fe}^{2+}$, and monovalent cations, such as $\mathrm{Na}^{+}$, which ultimately disturbs the biological metabolism of the cell (Papanikolaou 2005).

The results clearly indicated that there was a significant correlation $(P \leq 0.01)$ with $\mathrm{Mn}$ and HPLC-B(a)P and $(P \leq 0.05)$ with $\mathrm{Pb}$. These similarities show that the geological structure and composition of rocks represent the sources of heavy metals and determine chemical parameters in water samples (Issa and Alshatteri 2018). Significant differences were found with respect to the first round of sampling at sites S2, S3, S12 and S13. The results of the current study agreed with the WHO guideline of $2 \mathrm{mg} / \mathrm{L}\left(2000 \mu \mathrm{g} . \mathrm{L}^{-1}\right)$ and are higher than the results of Hussain et al., 2017 (0.00-0.01 mg. L), Ehi-Eromosele and Okiei 2012 (0.020 to 0.120 mg. L) and Malkani 
et al. 2019 (0.027 to $0.053 \mathrm{mg}$. L) for copper in drinking water. Levels of $\mathrm{Cu}$ in the current study ranged from 0

448 to $0.88 \mathrm{mg}$.L. Copper poisoning will result in chronic anemia (Acharya et al. 2008) or death due to nervous 449 system, liver, and kidney failure if large quantities of copper compounds are consumed (Sharma and Sharma 450 2020).

451 The manganese results revealed a negative correlation with $\mathrm{Cu}$ and a positive correlation with $\mathrm{Pb}$, with 452 values of -0.008 and 0.02 , respectively. At levels exceeding $0.1 \mathrm{mg} / \mathrm{L}$, manganese in water manifests an 453 undesirable taste in beverages and stains sanitary ware and laundry (Table 2) and accumulates deposits in the 454 distribution system. Concentrations below $0.4 \mathrm{mg} / \mathrm{L}$ are usually acceptable to consumers according to WHO 455 2011; moreover, a concentration of $0.2 \mathrm{mg} / \mathrm{L}$ will form a black coating on pipes. The health-based value of 0.4 $456 \mathrm{mg} / \mathrm{L}$ for manganese is lower than the acceptability threshold of $0.4 \mathrm{mg} / \mathrm{L}$ (WHO 2011). Manganese deficiency 457 can cause serious health problems, including weak bones (osteoporosis), muscle and joint pain, and sexual 458 dysfunction (Zofkova et al. 2017). Human exposure to higher amounts of manganese can result in severe 459 disorders in the nervous system, and long-term exposure can cause permanent neurological effects (USEPA 460 2004). The maximum concentration of manganese $\left(0.38 \mathrm{mg} \mathrm{L}^{-1}\right)$ was less than the WHO permissible limit. 461 Zainulabdeen (2018) concluded that the water supplied to consumers is of good quality, but the periodic 462 distribution of water may cause damage to the distribution network.

463

464 Table 2 Mean levels of heavy metals ( $\mathrm{Co}, \mathrm{Pb}, \mathrm{Cu}, \mathrm{Mn}$ ) in water samples at studied sites during summer and winter $465 \quad\left(\mathrm{mg} \mathrm{L}^{-1}\right)$.

466

\begin{tabular}{ccccccccc}
\hline site & \multicolumn{2}{c}{ Cobalt (Co) } & \multicolumn{2}{c}{ Lead $(\mathrm{Pb})$} & \multicolumn{2}{c}{ Copper $(\mathrm{Cu})$} & \multicolumn{2}{c}{ Manganese (Mn) } \\
\hline & Summer & Winter & Summer & Winter & Summer & Winter & Summer & Winter \\
1 & 0.061 & 0.054 & 0.047 & 0.060 & 0.004 & 0.006 & 0.073 & 0.127 \\
2 & 0.031 & 0.040 & 0.037 & 0.080 & 0.00 & 0.004 & 0.083 & 0.113 \\
3 & 0.055 & 0.080 & 0.033 & 0.073 & 0.00 & 0.00 & 0.057 & 0.103 \\
4 & 0.031 & 0.053 & 0.000 & 0.023 & 0.350 & 0.133 & 0.063 & 0.070 \\
5 & 0.027 & 0.093 & 0.037 & 0.043 & 0.087 & 0.102 & 0.077 & 0.113 \\
6 & 0.038 & 0.067 & 0.070 & 0.100 & 0.460 & 0.647 & 0.060 & 0.090 \\
7 & 0.054 & 0.070 & 0.003 & 0.030 & 0.143 & 0.100 & 0.016 & 0.010 \\
8 & 0.109 & 0.103 & 0.000 & 0.027 & 0.00 & 0.000 & 0.227 & 0.277 \\
9 & 0.100 & 0.153 & 0.030 & 0.073 & 0.160 & 0.177 & 0.050 & 0.117 \\
10 & 0.114 & 0.149 & 0.067 & 0.043 & 0.213 & 0.263 & 0.093 & 0.080 \\
11 & 0.101 & 0.200 & 0.050 & 0.08 & 0.067 & 0.070 & 0.053 & 0.123 \\
12 & 0.080 & 0.160 & 0.047 & 0.073 & 0.00 & 0.000 & 0.090 & 0.143 \\
13 & 0.059 & 0.063 & 0.000 & 0.030 & 0.00 & 0.000 & 0.110 & 0.130 \\
\hline
\end{tabular}


$469 \mathrm{~B}(\mathrm{a}) \mathrm{P}$ measurement is more accurate with HPLC than ELISA kits, and detected levels were higher during the wet season than during the dry season. Lower carcinogenic risks were obtained when an ELISA kit was used, and all results of total risks (oral and skin exposure) were lower than those of the HPLC method. Carcinogenic risks for both methods were within acceptable ranges and did not surpass standards, with the highest levels found in children in comparison with adults. The most significant contributors to variation in overall cancer risk appear to be fluctuations in the concentration of $\mathrm{B}(\mathrm{a}) \mathrm{P}(\mathrm{Cw})$ in various sampling locations, followed by exposure length (ED). High levels of lead were measured in the studied drinking water. The risk from heavy metal exposure (lead) is almost negligible in comparison with the risk from B(a)P. This study may open the gateway to future endeavors with respect to PAHs, and Iraqi drinking water is contaminated with heavy metals.

\section{Author Declaration}

\section{Research Ethics}

482 Every element of the work discussed in this manuscript that does not include human patients or animals is 483 presented within the manuscript.

\section{Consent for publication}

"Not applicable"

\section{Availability of data and materials}

All data generated or analyzed during this study are included in this published article [and its supplementary 488 information files].

\section{Competing Interest}

We would like to confirm that this publication (Profiling of seasonal variation in and cancer risk assessment of benzo(a)pyrene and heavy metals in drinking water from the Kirkuk region, Iraq) is free of any known conflicts of interest. This study has received no direct financial funding that could have affected its results.

\section{Funding}

We wish to confirm that there are no sources of funding for the work and that the expenses were covered by the authors themselves.

\section{Intellectual Rights}

We confirm that the protection of intellectual property associated with this work has been carefully considered and that there are no intellectual property impediments to publication, including publication timing. As a result, we confirm that we have complied with the intellectual property policies of our respective institutions.

\section{Authors' Contributions}



based on the following criteria:

1. Significant contributions to the work's conception or design; or the work's acquisition, analysis, or interpretation of data; AND

2. Drafting the work or critically revising it for important intellectual content; AND 3. Final approval of the version to be published; AND reliability of the work are addressed; AND

All listed authors (Awaz Bahrooz Mohammed ${ }^{1}$, Siraj Muhammed Abdulla Goran ${ }^{2}$ and Abhrajyoti Tarafdar ${ }^{3}$ ) met the Environmental Science and Pollution Journal criteria. We attest that all authors contributed significantly to

512 the creation of this manuscript, each having fulfilled criteria as established by the Environmental Science and

513 Pollution Journal. We confirm that all mentioned authors have read and accepted the manuscript. We confirm

514 that all named authors have accepted the order of authors mentioned in the manuscript.

\section{Contact with the Editorial Department}

516 The corresponding author of this manuscript is as follows:

517 (Siraj Muhammed Abdulla Goran; siraj.abdulla@su.edu.krd

Contact Numbers: +9647504546250; +9647724466884; +9647808227000)

This Corresponding Author, we understand, is the only point of contact for the Editorial Process (including the procedure for submitting articles to the editor and direct contact with the office). He is in charge of keeping the other authors informed about development, revision submissions, and proof acceptance.

Undersigned authors agree with all of the above. 


\section{Acknowledgments}

We heartily express our sincere thanks to the Salahaddin University College of Science-Environmental Science and Health Department for heavy metal analysis. Special thanks are given to the Ministry of Sciences and Technology, Baghdad, Iraq for analysis of benzo(a)pyrene by HPLC.

\section{References}

- Acharya GD, Hathi MV, Patel AD, Parmar KC (2008) Chemical properties of groundwater in Bailoda Taluka region, north Gujarat, India. E J Chem 5(4):792-796.

- Aleseyyed SB, Norouzi S, Khodabakhshi M (2018) Evaluation of Heavy Metals in Drinking Water Resources in Urban and Rural Areas of Hamadan Province in 2016. Journal of Environmental Health and Sustainable Development 3(1): 448-53.

- Alrakabi MH, Ramadan ES (2020) Determination of Heavy elements in Drinking Water from Different Regions of Baghdad City (Iraq) Using EDXRF Spectrometer. Al-Mustansiriyah Journal of Science 28 (1): 142-148, nov. 2017. ISSN 2521-3520. Available at: <http://mjs.uomustansiriyah.edu.iq/ojs1/index.php/MJS/article/view/324> . Date accessed: 30 aug. 2020. doi:http://dx.doi.org/10.23851/mjs.v28i1.324.

- ATSDR (1990) Toxicological Profile for Benzo(a)pyrene, May. Prepared by ICF-Clement under Contract No. 68-02-4235 for USDHHS, PHS, CDC, ATSDR, in collaboration with the United States Environmental Protection Agency (U.S. EPA), with technical editing/document preparation by Oak Ridge National Laboratory. ATSDR/TP-88/05. ATSDR, CDC. Atlanta, Georgia.

- Badawy MI, Emababy MA (2010) Distribution of polycyclic aromatic hydrocarbons in drinking water in Egypt. Desalination Jour. 251: 34-40

- Baird RB, Eaton AD, Rice EU (2017) Stander Methods for the examination of water and wastewater, $23^{\text {rd }}$ Edition. American Public Health Association (APHA) in collaboration with American Water Works Association and Water Environment Federation, 800 street, NW, Washington, DC. 20001-3710. 
- Brochin R, Leone S, Phillips D, Shepard N, Zisa D, Angerio A. The cellular effect of lead poisoning and its clinical picture. GUJHS (2008) 5(2): 1-8.

- Carpenter DO, Arcaro KF, Spink DC (2002) Understanding the human health effects of chemical mixtures, Environ. Health Perspect. J. 110 (Suppl. 1) 25-42.

- Chen HW (2004) Determination of polycyclic aromatic hydrocarbons in water by solid-phase microextraction and liquid chromatography. Anal. Sci. J. 20:1383-1388.

- Chen HW (2007) Distribution and Risk Assessment of Polycyclic Aromatic Hydrocarbons in Household Drinking Water. Bull Environ Contam. Toxicology 78:201-205.

- Chen J, Fan B, Li J, Wang X, Li W, Cui L, Liu Z (2020) Development of human health ambient water quality criteria of 12 polycyclic aromatic hydrocarbons (PAH) and risk assessment in China. Chemosphere J. 252. 126590. http://www.sciencedirect.com/science/article/pii/S0045653520307839

- Ehi-Eromosele CO, Okiei WO (2012) Heavy Metal Assessment of Ground, Surface and Tap Water Samples in Lagos Metropolis Using Anodic Stripping Voltammetry. Resources and Environment J. 2(3): 82-86 DOI: $10.5923 /$ j.re.20120203.01

- EPA (2011) Exposure factors handbook. Washington, D.C.: United States Environmental Protection Agency 1436 p. Available from: https://cfpub.epa.gov/ncea/ risk/recordisplay.cfm?deid=236252

- Federal-Provincial-Territorial Committee (FPTC) (2015) Benzo[a]pyrene in Drinking Water. Health Canada 48pp.

- Flora SJS, Mittal M, Mehta A (2008) Heavy metal induced oxidative stress and its possible reversal by chelation therapy. Indian J Med Res. 128: 501-523.

- Hanaa M, Eweida A, Farag A (2000) Heavy metals in drinking water and their environmental impact on human health. International Conference on Environmental Hazards Mitigation, Cairo University, Egypt. P. 542-556.

- Hussain J, Husain I, Arif M, Gupta N (2017) Studies on heavy metal contamination in Godavari river basin. Appl Water Sci. 7:4539-4548.

- Ibrahim SA, Al-Tawash BS, Abed MF (2018) Environmental assessment of heavy metals in surface and groundwater at Samarra City, Central Iraq. Iraqi Journal of Science 59(3A):1277-1284. DOI:10.24996/ijs.2018.59.3A.16

- Integrated Risk Information System (IRIS) and U.S. Environmental Protection Agency (1988) Copper; CASRN 7440-50-8. $7 \mathrm{pp}$.

- International Agency for Research on Cancer (1987). IARC monographs on the evaluation of carcinogenic risk of chemicals to humans. Supplement No. 7. Overall evaluations of carcinogenicity: an updating of IARC monographs Volume 1 to 42. Lyon: International Agency for Research on Cancer. http://monographs.iarc.fr/ ENG/Monographs/suppl7/ [Accessed on 20th January, 2015]

- Issa HM, Alshatteri AH (2018) Assessment of Heavy Metals Contamination in Drinking Water of Garmian Region, Kurdistan, Iraq. UHD Journal of Science and Technology 2 (2): 40-53

- Itodo AU, Sha'Ato R, Arowojolu MI (2018) Polycyclic aromatic hydrocarbons in water samples from a Nigerian bitumen seepage: Gas chromatography- mass spectrometry quantification. Bangladesh J. Sci. Ind. Res. 53(4): 319-326. 
- Jaishankar M, Tseten T, Anbalagan N, Mathew BB, Beeregowda KN (2014) Toxicity, mechanism and health effects of some heavy metals. Interdiscip Toxicol 7(2): 60-72. doi: 10.2478/intox-2014-0009

- Jedrychowski WA, Perera FP, Tang D, Rauh V, Majewska R, Mroz E, et al (2013) The relationship between prenatal exposure to airborne polycyclic aromatic hydrocarbons (PAHs) and PAH-DNA adducts in cord blood. J Expo Sci Environ Epidemiol 23: 371-377.

- Karyab H, Yunesian M, Nasseri S, Rastkari N, Mahvi A, Nabizadeh R (2016) Carcinogen Risk Assessment of Polycyclic Aromatic Hydrocar-bons in Drinking Water, Using Probabilistic Approaches. Iran J Public Health 45(11): 1455-1464.

- Lee G, Bigham JM, Faure G (2002) Removal of trace metals by coprecipitation with Fe, Al and Mn from natural waters contaminated with acid mine drainage in the Ducktown Mining District, Tennessee. Applied Geochemistry 17(5): 569-581.

- Malkani P, Sagar AKRA, Singh P, Kumar Y (2019) Assessment of Physico-chemical Drinking Water River. Current Journal of Applied Science and Technology 38(6), 1-12. https://doi.org/10.9734/cjast/2019/v38i630417

- MDH (2020) Toxicological Summary for: Manganese. Minnesota Department of Health. CAS: 743996-5 8pp.

- Mebrahtu G, Zerabruk S (2011) Concentration of Heavy Metals in Drinking Water from Urban Areas of the Tigray Region, Northern Ethiopia. CNCS, Mekelle University 3 (1):105-121.

- Mohammed AB, Goran SMA, Al-Taee MM (2010) The efficiency of drinking -water-treatment processes in removing of some PAHs compounds from water in Erbil city-Iraq, J.Thi-Qar Sci 2(3): 40pp.

- Mukherjee I, Singh UK, Singh RP, Anshumali Kumari D, Jha PK, Mehta P (2020) Characterization of heavy metal pollution in an anthropogenically and geologically influenced semi-arid region of east India and assessment of ecological and human health risks. Sci. Total Environ. 705. https://doi.org/10.1016/j.scitotenv.2019.135801

- Nagajyoti PC, Lee KD, Sreekanth TVM (2010) Heavy metals, occurrence and toxicity for plants: a review. Environ Chem Lett 8(3): 199-216.

- Nambatingar N, Clement Y, Merle A, New Mahamat T, Lanteri P 2017 Heavy Metal Pollution of Chari River Water during the Crossing of N'Djamena (Chad). Toxics. 12; 5(4):26. doi: 10.3390/toxics5040026. PMID: 29051458; PMCID: PMC5750554.

- OEHHA (2010) Public health goals for chemicals in drinking water: benzo(a)pyrene. Office of Environmental Health Hazard Assessment, California Environmental Protection Agency, Sacramento, CA www.oehha.ca.gov/water/phg/pdf/091610Benzopyrene.pdf.

- OXFAM (2017) The Case for Improved Water Resource Management In Kirkuk Governorate, Iraq. European Union Civil Protection and Humanitarian Aid 31pp.

- Pan E, Sun H, Xu Q, Zhang Q, Liu L, Chen X, Xu Y (2015) Polycyclic aromatic hydrocarbons concentrations in drinking water in villages along the Huai river in China and their association with high cancer incidence in local population. BioMed Res. Int. 1-10.

- Papanikolaou NC, Hatzidaki EG, Belivanis S, Tzanakakis GN, Tsatsakis AM (2005) Lead toxicity update. A brief review. Med Sci Monitor. 11(10): RA329. 
- Rajasekhar B, Nambi IM, Govindarajan SK (2018) Human health risk assessment of ground water contaminated with petroleum PAHs using Monte Carlo simulations: A case study of an Indian metropolitan city. Journal of Environmental Management 205: 183-191

- Rajendran P, Ekambaram G, Sakthisekaran D (2008) Cytoprotective effect of mangiferin on benzo(a)pyrene-induced lung carcinogenesis in swiss albino mice. Basic Clin. Pharmacol Toxicol 103: 137-142.

- Rajendran P, Jayakumar T, Nishigaki I, Ekambaram G, Nishigaki Y, Vetriselvi J, et al (2013) Immunomodulatory effect of mangiferin in experimental animals with benzo(a)pyrene-induced lung carcinogenesis. Int J Bomed Sci 9: 68-74.

- Rajendran P, Rengarajan T, Nishigaki I, Ekambaram G, Sakthisekaran D (2014) Potent chemopreventive effect of mangiferin on lung carcinogenesis in experimental Swiss albino mice. J Cancer Res Ther 10: 1033- 1039.

- Rajkovic MB, Lacnjevac CM, Ralevic NR, Stojanovic MD, Toskovic DV, Pantelic GK, Ristic NM, Jovanic S (2008) Identification of metals (heavy and radioactive) in drinking water by indirect analysis method based on scale tests. Sensors 8: 2188-2207.

- Saha N, Rahman MS, Ahmed MB, Zhou JL, Ngo HH, Guo W (2017) Industrial metal pollution in water and probabilistic assessment of human health risk. J. Environ. Manag. 185: 70-78.

- Sharma AK, Sharma S (2020) Effect of Heavy Metals in Drinking Water. International Journal for Scientific Research and Development 8 (6): 2321-0613.

- Singh R, Gautam N, Mishra A, Gupta R (2011) Heavy metals and living systems: An overview. Indian J Pharmacol. 43(3):246-253. doi:10.4103/0253-7613.81505

- Southworth GR (1979) The role of volatilization in removing polycyclic aromatic hydrocarbons from aquatic environments. Bulletin of environmental contamination and toxicology 21:507-514.

- Tarafdar A, Chawda S, Sinha A (2018) Health Risk Assessment from Polycyclic Aromatic Hydrocarbons https://doi.org/10.1080/10406638.2018.1492426

- Tarafdar A, Oh MJ, Nguyen-Phuong Q, Kwon JH (2020). Profiling and potential cancer risk assessment on children exposed to PAHs in playground dust/soil: a comparative study on poured rubber surfaced and classical soil playgrounds in Seoul. Environ. Geochem. Health 42, 1691-1704. https://doi.org/10.1007/s10653-019-00334-2

- Tarafdar A, Sinha A (2017a) Estimation of decrease in cancer risk by biodegradation of PAHs content from an urban traffic soil. Environ. Sci. Pollut. Res. 24, 10373-10380. https://doi.org/10.1007/s11356017-8676-3

- Tarafdar A, Sinha A (2017b) Cancer Risk Assessment of Polycyclic Aromatic Hydrocarbons in the Soils and Sediments of India: A Meta-Analysis. Environ. Manage. 60, 784-795. https://doi.org/10.1007/s00267-017-0920-6

- Tarafdar A, Sinha A (2018) Health risk assessment and source study of PAHs from roadside soil dust of a heavy mining area in India. Arch. Environ. Occup. Heal. 1-11. https://doi.org/10.1080/19338244.2018.1444575 
- Tarafdar A, Sinha A (2018a) Public health risk assessment with bioaccessibility considerations for soil PAHs at oil refinery vicinity areas in India. Sci. Total Environ. 616-617, 1477-1484. https://doi.org/10.1016/j.scitotenv.2017.10.166

- Tarantini A, Maitre A, Lefebvre E, Marques M, Rajhi A, Douki T (2011) Polycyclic aromatic hydrocarbons in binary mixtures modulate the efficiency of benzo[a]pyrene to form DNA adducts in human cells. Toxicology 279: 36-44.

- United Nation Environmental Program (UNEP) (1989) Comparative toxicity test of water accommodated fraction of oil dispersants to marine organisms. Reference methods for marine pollution 45: $21 \mathrm{pp}$.

- United States Environmental Protection Agency (USEPA) (2001) Risk Assessment Guidance for Superfund (RAGS) Volume III - Part A: Process for Conducting Probabilistic Risk Assessment, Appendix B. Off. Emerg. Remedial Response U.S. Environ. Prot. Agency III

- United States Environmental Protection Agency (USEPA) (2004) Risk assessment guidance for superfund. Vol. 1, Human health evaluation manual (part E, supplemental guidance for dermal risk assessment) [Internet]. Washington, D.C. 156 p. Report No.: EPA/540R/99/005. Available from: https:// www.epa.gov/sites/production/files/2015-09/documents/part_e_final_revision_10-03-07.pdf

- United States Environmental Protection Agency (USEPA) (2008) Provisional Peer Reviewed Toxicity Values for Cobalt (CASRN 7440-48-4) EPA/690/R-08/008F.

- United States Environmental Protection Agency (USEPA) (2010) Fluoride: Dose-Response Analysis for Non-cancer Effects, Health and Ecological Criteria Division Office of Water Washington, D.C. 820-R10-019 $103 \mathrm{pg}$.

- United States Environmental Protection Agency (USEPA) (2011) Exposure Factors Handbook: 2011 Edition, U.S. Environmental Protection Agency. Washington, DC. https://doi.org/EPA/600/R-090/052F

- United States Environmental Protection Agency (USEPA) (2017) Toxicological review of benzo[a]pyrene. Washington, D.C.: 234 p. Report No.: EPA/635/R-17/003Fa Available from: https://cfpub.epa.gov/ncea/iris/iris_documents/documents/toxreviews/0136tr.pdf

- Walsh AA, Szklarz GD, Scott EE (2013) Human cytochrome P450 1A1 structure and utility in understanding drug and xenobiotic metabolism. J Biol Chem 288: 12932-12943.

- WHO (2003) Polynuclear aromatic hydrocarbons in Drinking-water, Background document for development of WHO Guidelines for Drinking-water Quality. Guidelines for drinking-water quality, $2^{\text {nd }}$ ed. Addendum to Vol. 2. Health criteria and other supporting information. World Health Organization, Geneva $27 \mathrm{p}$

- World Health Organization (WHO) (2011) Guidelines for Drinking-Water Quality, $4^{\text {th }}$ ed.; World Health Organization: Geneva, Switzerland 541pp. Available online: http://www.who.int/water_sanitation_health/dwq/GDWQ2004web (accessed on 1 September 2012).

- Yan M, Nie H, Wang W, Huang Y, Wang J (2018) Occurrence and Toxicological Risk Assessment of Polycyclic Aromatic Hydrocarbons and Heavy Metals in Drinking Water Resources of Southern China. International Journal of Environmental Research. and Public Health 15, 1422; doi:10.3390/ijerph15071422. 
- Zainulabdeen IH (2018) Study of the properties of drinking water for Kirkuk city and its pollution in some areas. MATEC Web of Conferences 162, 05008. p. 1-6 https://doi.org/10.1051/matecconf/201816205008.

- Zofkova I, Davis M, Blahos J (2017) Trace Elements Have Beneficial, as Well as Detrimental Effects on Bone Homeostasis I. Physiol. Res. J. 66: 391-402. 
Figures
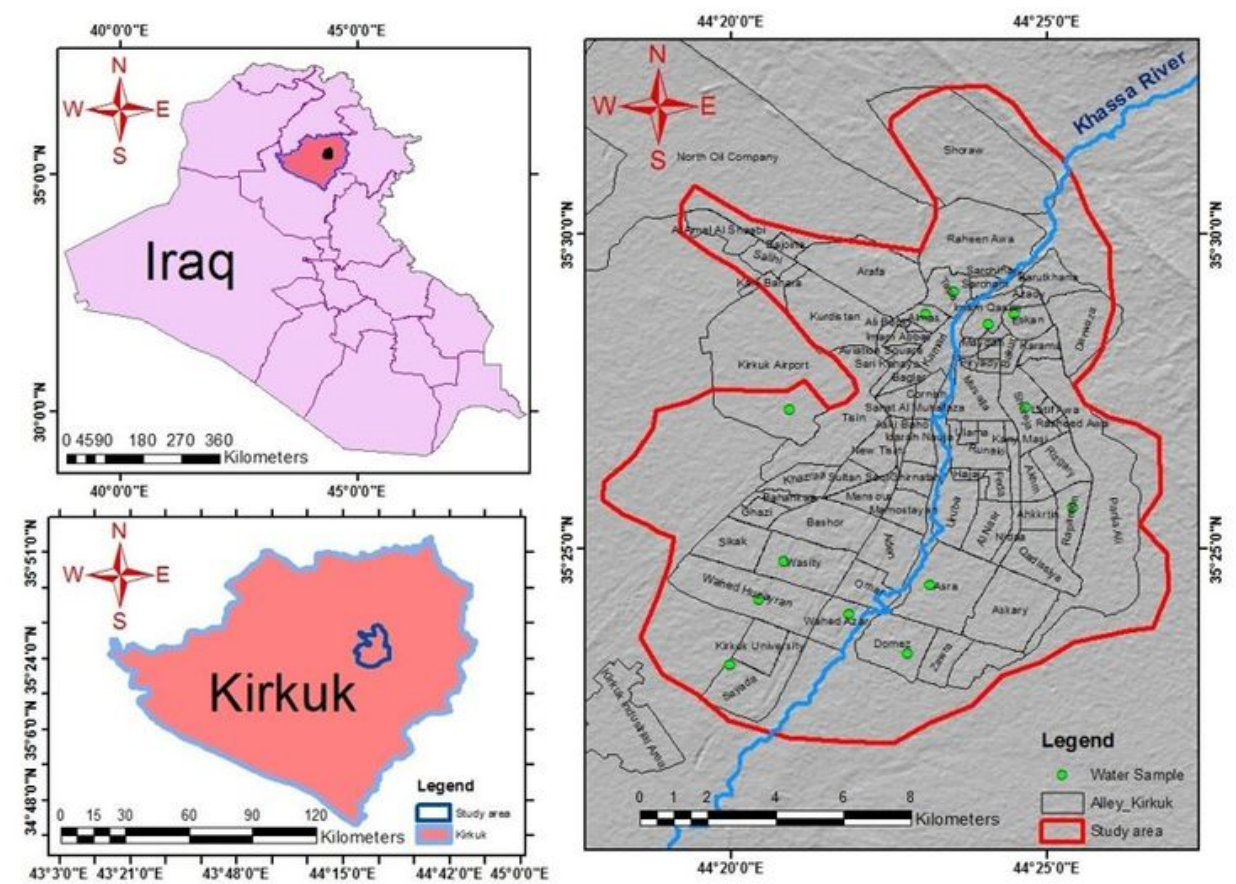

(a)

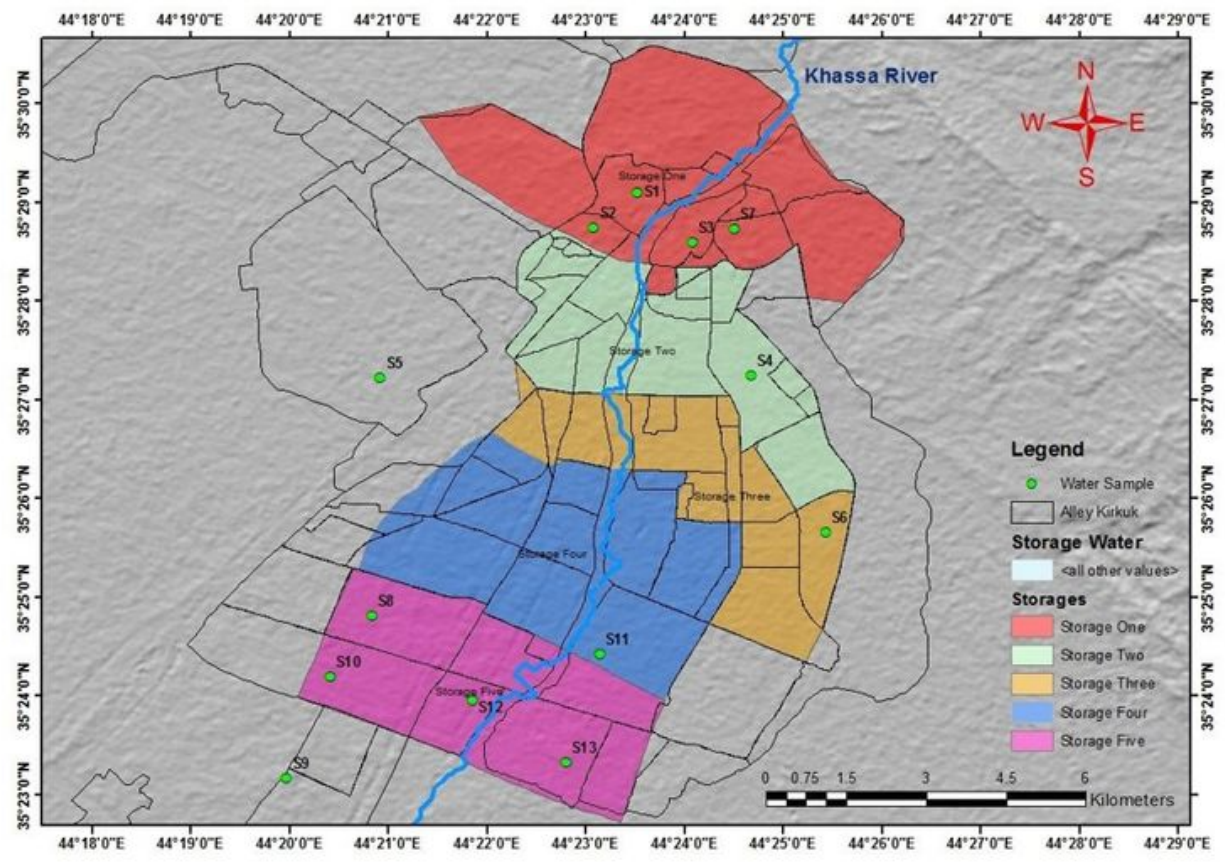

(b)

\section{Figure 1}

(a) Iraq map and sampling sites in Kirkuk city and (b) water tanks ST1, ST2, ST3, ST4 and ST5 that feed all areas within Kirkuk city. 

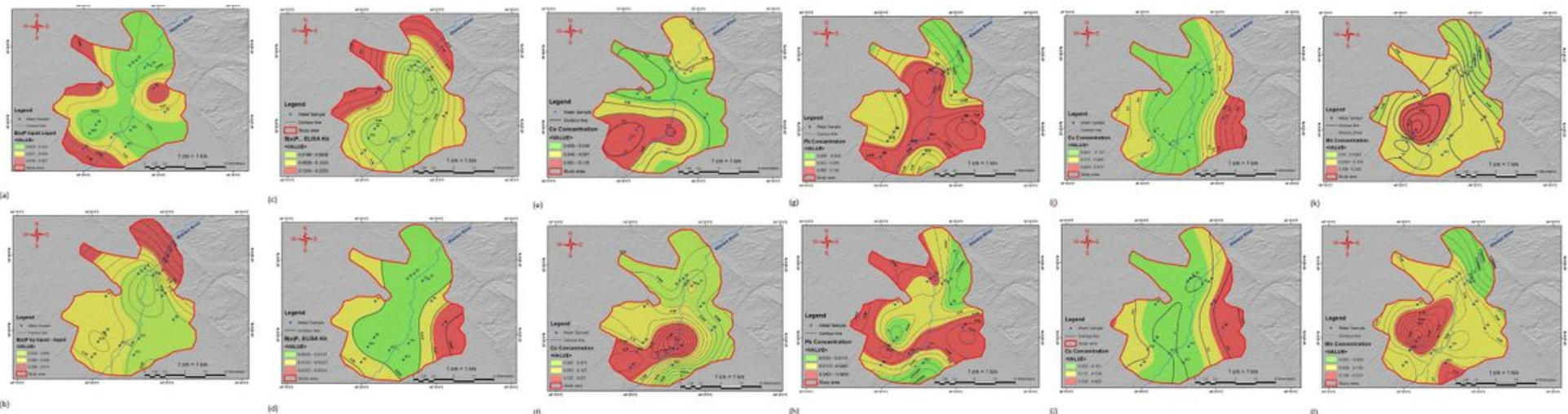

Figure 2

Seasonal variation in ( $a-d)$ benzo(a)pyrene concentration determined by ( $a$ and $b$ ) liquid-liquid extraction and (b and c) ELISA, where ( $a$ and c) correspond with wet and ( $b$ and d) with dry seasons. (e and f) Cobalt concentrations during wet and dry seasons. ( $g$ and $h$ ) Lead concentrations during wet and dry seasons. ( $i$ and j) Copper concentrations during wet and dry seasons. ( $k$ and l) Manganese concentrations during wet and dry seasons. 

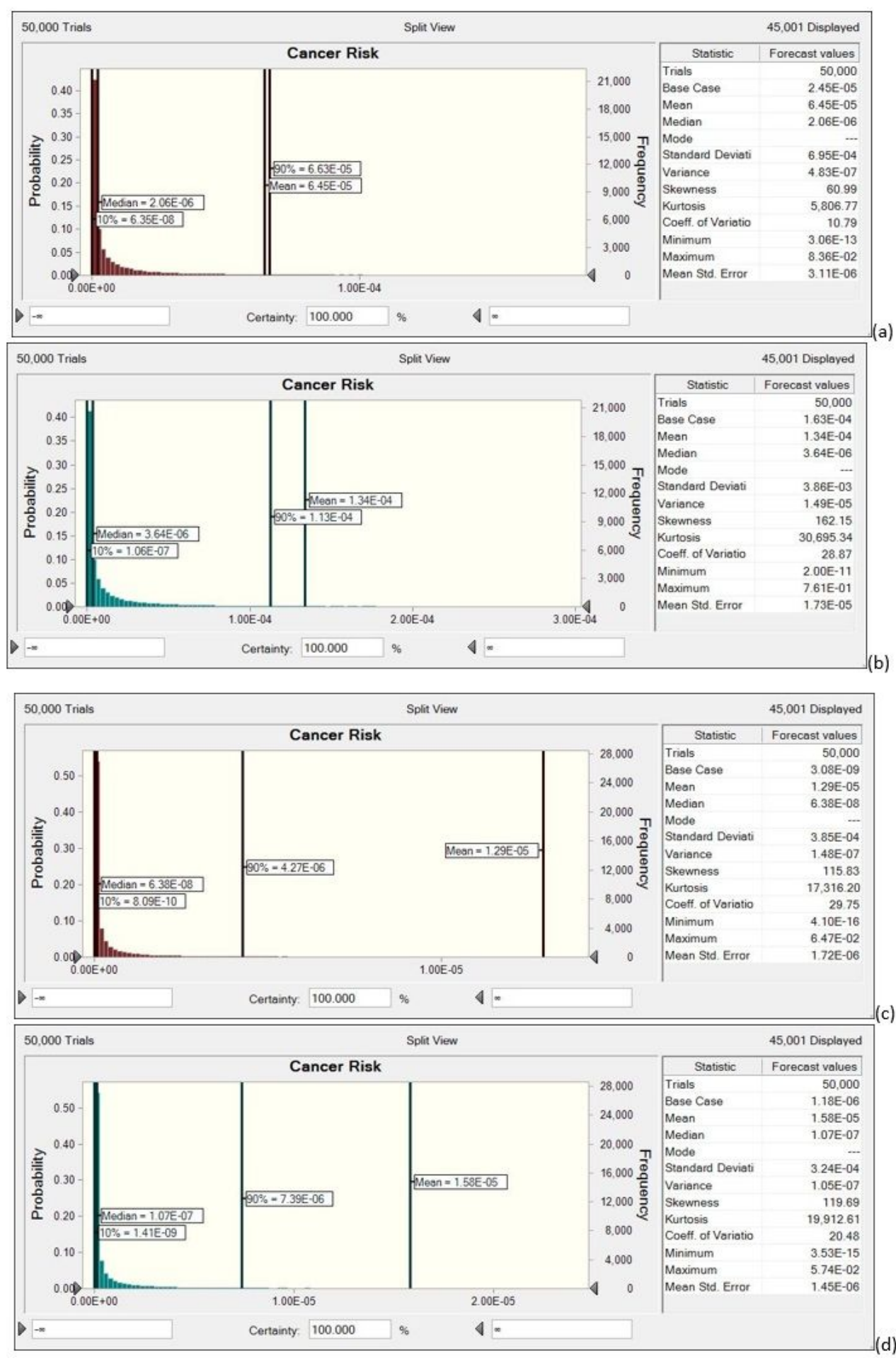

\section{Figure 3}

The probability density functions of cancer risk (liq-liq extraction) predicted in winter season for (a) children and (b) adults and in summer season for (c) children and (d) adults from B(a)P content of drinking water. 

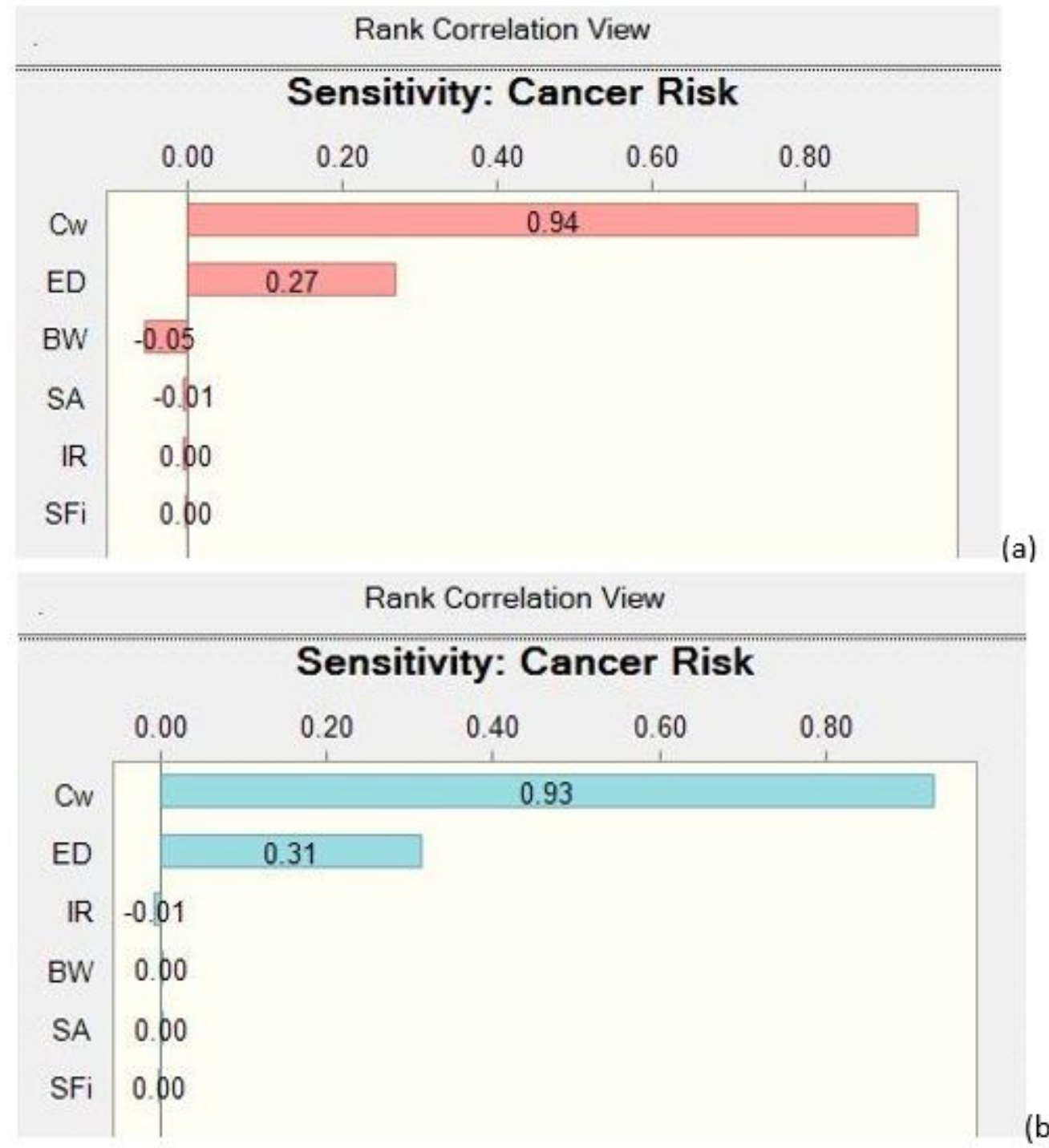

Figure 4

Sensitivity analysis of cancer risk parameters in two groups: children (a) and adults (b).

\section{Supplementary Files}

This is a list of supplementary files associated with this preprint. Click to download.

- SupplementaryData1.docx 